\title{
Sectorverkenning arbeidsmarkt Zuid-Limburg : De metaal- en elektrotechnische industrie
}

Citation for published version (APA):

Horbeek, J., \& de Grip, A. (1996). Sectorverkenning arbeidsmarkt Zuid-Limburg : De metaal- en elektrotechnische industrie. Researchcentrum voor Onderwijs en Arbeidsmarkt, Faculteit der Economische Wetenschappen. ROA Reports No. 11 https://doi.org/10.26481/umarep.1996011

Document status and date:

Published: 01/01/1996

DOI:

10.26481/umarep.1996011

Document Version:

Publisher's PDF, also known as Version of record

\section{Please check the document version of this publication:}

- A submitted manuscript is the version of the article upon submission and before peer-review. There can be important differences between the submitted version and the official published version of record.

People interested in the research are advised to contact the author for the final version of the publication, or visit the DOI to the publisher's website.

- The final author version and the galley proof are versions of the publication after peer review.

- The final published version features the final layout of the paper including the volume, issue and page numbers.

Link to publication

\footnotetext{
General rights rights.

- You may freely distribute the URL identifying the publication in the public portal. please follow below link for the End User Agreement:

www.umlib.nl/taverne-license

Take down policy

If you believe that this document breaches copyright please contact us at:

repository@maastrichtuniversity.nl

providing details and we will investigate your claim.
}

Copyright and moral rights for the publications made accessible in the public portal are retained by the authors and/or other copyright owners and it is a condition of accessing publications that users recognise and abide by the legal requirements associated with these

- Users may download and print one copy of any publication from the public portal for the purpose of private study or research.

- You may not further distribute the material or use it for any profit-making activity or commercial gain

If the publication is distributed under the terms of Article $25 \mathrm{fa}$ of the Dutch Copyright Act, indicated by the "Taverne" license above, 


\title{
Sectorverkenning arbeidsmarkt Zuid-Limburg: De metaal- en elektrotechnische industrie
}

\author{
ROA-R-1996/11
}

Job Horbeek
Andries de Grip

Researchcentrum voor Onderwijs en Arbeidsmarkt

Rijksuniversiteit Limburg

Faculteit der Economische Wetenschappen en Bedrijfskunde

Maastricht, augustus 1996 
ISBN 90-5321-191-8 


\section{Inhoud}

Bladzijde

Voorwoord

i

1 Bedrijven in de metaal- en elektrotechnische industrie: een landelijke verkenning

1.1 Ontwikkeling van de werkgelegenheid

1.2 Achtergronden van de werkgelegenheidsontwikkelingen

1.3 Achtergronden per bedrijfsklasse

2 Bedrijven in de Zuid-Limburgse metaal- en elektrotechnische industrie

2.1 Ontwikkeling van de regionale werkgelegenheid

2.2 Achtergronden van de werkgelegenheidsontwikkelingen

3 Beroepen in de metaal- en elektrotechnische industrie

4 Opleidingen voor de metaal- en elektrotechnische industrie 



\section{Voorwoord}

In april 1995 kreeg het Researchcentrum voor Onderwijs en Arbeidsmarkt van het RBA Zuid-Limburg de opdracht om de regionale arbeidsmarkt verbijzonderd naar bedrijfssector in beeld te brengen. Het doel van de opdracht was tweeledig. Enerzijds moest het onderzoek regionale arbeidsmarkt-informatie opleveren ten behoeve van de regionale scholingsplanning. Anderzijds beoogde het RBA met de produktie van de Sectorale Arbeidsmarktverkenningen Zuid-Limburg het proces van beleidsplanning en -controle te verbeteren.

Het ROA heeft in dit kader tot eind 1995 gewerkt aan de invulling van verkenningen voor een aantal bedrijfssectoren, die in eerste instantie bedoeld zijn voor intern gebruik bij de Arbeidsvoorzieningsorganisatie. Om een beeld te geven van de gevolgde aanpak, wordt in dit rapport verslag gedaan van de sectorverkenning voor de metaal- en elektrotechnische industrie. Daarbij is gebruik gemaakt van een groot aantal bestaande databronnen van het CBS, Landelijk Bureau Arbeidsvoorziening, ROA e.a., in combinatie met de binnen de regionale Arbeidsvoorzieningsorganisatie beschikbare vacature- en werkzoekenden gegevens en expertise van de consulenten van de Arbeidsbureaus. De aldus gegenereerde informatie werd door het RBA verwerkt in de scholingsplanning, die overigens niet is opgenomen in dit rapport.

De opzet van het rapport is als volgt. Allereerst wordt een beeld geschetst van de landelijke werkgelegenheidsontwikkelingen in de metaal- en elektrotechnische industrie. Daarna gaat hoofdstuk 2 in op de regionale werkgelegenheidsontwikkelingen. De hoofdstukken 3 en 4 beschrijven achtereenvolgens de landelijke én regionale werkgelegenheidsontwikkelingen in de beroeps- en opleidingssectoren die voor de metaal- en elektrotechnische industrie van belang zijn. Ten slotte worden in hoofdstuk 5 de belangrijkste conclusies van het rapport samengevat.

De arbeidsmarktverkenning is uitgevoerd door drs. J. Horbeek onder begeleiding van dr. A. de Grip. Drs. Th. Mensen verzorgde de begeleiding van het onderzoeksproject vanuit het RBA Zuid-Limburg 


\section{Bedrijven in de metaal- en elektrotechnische industrie: een landelijke verkenning}

In hoofdstuk 1 staan de werkgelegenheidsontwikkelingen in de metaal- en elektrotechnische industrie centraal. In paragraaf $1.1 \mathrm{zal}$ de metalektro-sector worden gepositioneerd ten opzichte van andere bedrijfssectoren op basis van het werkgelegenheidsaandeel en de groei van de werkgelegenheid. In paragraaf 1.2 wordt ingegaan op de achtergronden van de werkgelegenheidsontwikkelingen. In paragraaf 1.3 zal per bedrijfsklasse worden ingegaan op de recente ontwikkelingen en de verwachte perspectieven voor de nabije toekomst. De belangrijkste cijfers zijn gebaseerd op de prognoses van het Centraal Plan Bureau (D-tabellen CEP, 1995). Aan de hand van deze prognoses wordt een beeld geschetst van de ontwikkelingen in de totale metalektro-sector tot en met 1996. De ontwikkelingen binnen de afzonderlijke bedrijfsklassen hebben betrekking op de jaren 1993-'95.

\subsection{Ontwikkeling van de werkgelegenheid}

In figuur 1.1 zijn de verschillende economische sectoren getypeerd op basis van de ontwikkeling van de werkgelegenheid tussen 1991 en 1995 en het aandeel in de totale werkgelegenheid in 1991. De bedrijfsklassen binnen de metalektro zijn in deze figuur bij naam genoemd.

Gezamenlijk zijn de metalektro bedrijfsklassen goed voor $7 \%$ van de totale Nederlandse werkgelegenheid. Zes bedrijfsklassen bepalen het gezicht van de branche. De drie grootste bedrijfsklassen zijn de metaalproduktenindustrie, de machine-industrie en de elektrotechnische industrie. Kleiner van omvang zijn de de basismetaal, de transportmiddelenindustrie en de instrumentenindustrie ${ }^{1}$. Wanneer de positie van de metalektro-bedrijfsklassen in de figuur worden vergeleken met die van andere sectoren, blijkt dat de transportmiddelenindustrie en de basismetaalindustrie de sterkst krimpende sectoren in de Nederlandse economie zijn. Ook de grotere metalektro sectoren onderscheiden zich alle drie in ongunstige zin van de andere sectoren in de Nederlandse economie.

Al met al is de metalektro te positioneren als een bedrijfstak die weliswaar nog steeds een fors deel van de werkgelegenheid voor haar rekening neemt, maar zich in werkgelegenheidsopzicht in de afgelopen jaren relatief ongunstig heeft ontwikkeld (CPB, 1995).

1. Deze sector is niet opgenomen in de figuur. 
Figuur 1.1

Typering economische sectoren op basis van werkgelegenheidsaandeel en -groei 1991-'95

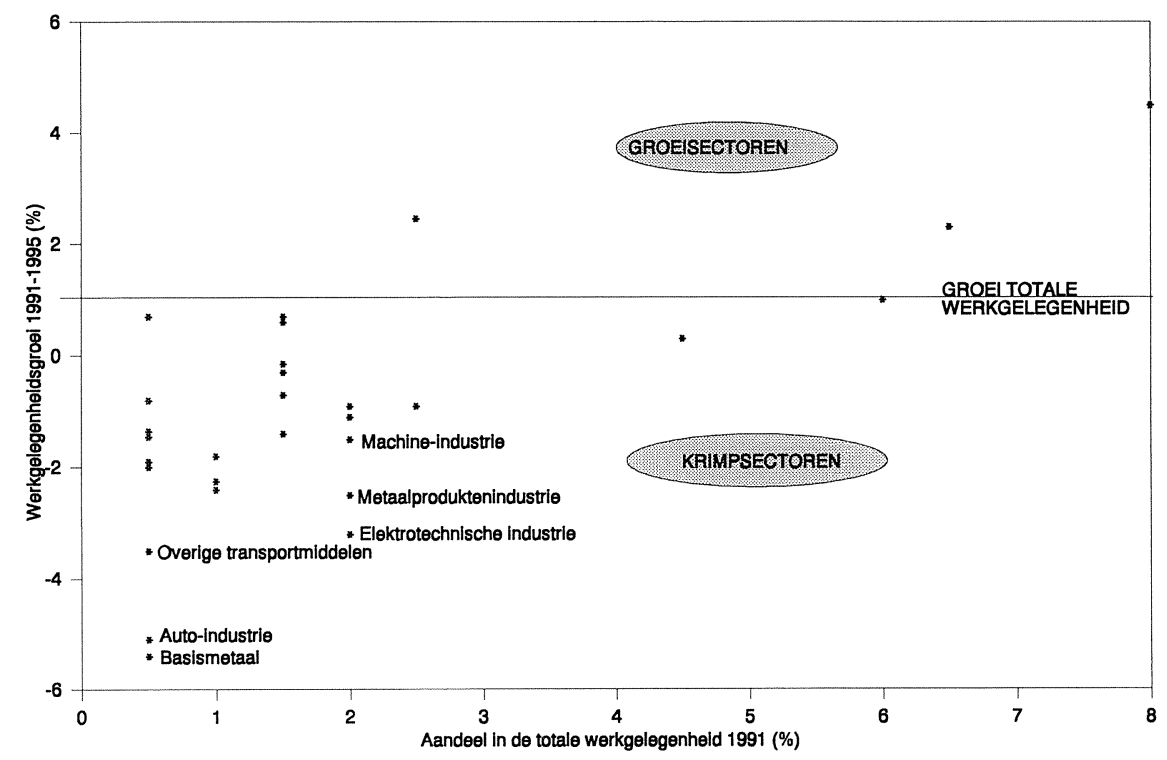

Bron: CPB

Uit figuur 1.2 blijkt, dat de metalektro bovendien te positioneren is als een sector die weliswaar zeer conjunctuurgevoelig is, maar weinig flexibele arbeidskrachten in dienst heeft (ROA, 1995). Uit de gesprekken met consulenten van de Arbeidsvoorzieningsorganisatie blijkt overigens wel, dat het aantal flexibele arbeidskrachten in de metalektro-sector in een hoog tempo toeneemt.

Uit onderzoek van de branche-organisatie FME blijkt eveneens dat er sprake is van een duidelijke toename van het gebruik van flexibel inzetbare werknemers. Niet alleen maken bedrijven in de metalektro steeds meer gebruik van uitzendkrachten en tijdelijke aanstellingen, ook wordt steeds meer gebruik gemaakt van interne vormen van flexibiliteit: flexibilisering van arbeidstijden, part-time contracten, multiinzetbaarheid etc. (FME, 1995). 
Figuur 1.2

Conjunctuurgevoeligheid en flexibiliteit van de werkgelegenheid naar economische sector

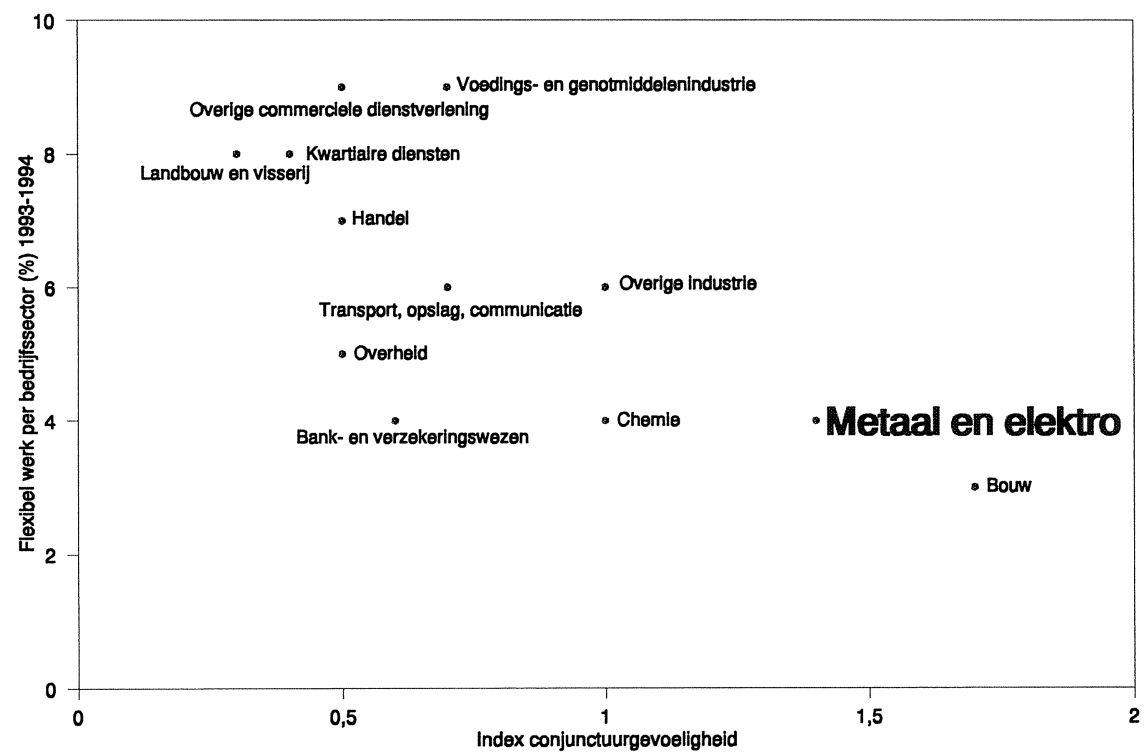

Bron: ROA/CBS

\subsection{Achtergronden van de werkgelegenheidsontwikkelingen}

In deze paragraaf worden de achtergronden van de ongunstige werkgelegenheidsontwikkelingen in de totale metaal- en elektrotechnische industrie geschetst. In paragraaf 1.2 worden de werkgelegenheidsontwikkelingen gerelateerd aan de afzetmarktontwikkelingen en de groei van de produktiviteit. In paragraaf 1.2 wordt ingegaan op de meer structurele achtergronden van de werkgelegenheidsreducties binnen de metalektro-sector.

\section{Afzetmarkt- en produktiviteitsontwikkelingen}

De werkgelegenheid in de metalektro daalt al sinds 1991. In 1995 kon de hoge economische groei het tij keren; in dat jaar stabiliseert zich de werkgelegenheid in de metalektro-sector. Het herstel van de werkgelegenheid zet in de metalektro dus een jaar later in dan in veel andere sectoren. Vanaf 1996 groeit de werkgelegenheid naar verwachting licht (zie figuur 1.3).

De werkgelegenheidsreducties in de metalektro zijn voor een groot deel terug te voeren op ongunstige afzetmarktontwikkelingen in het begin van de jaren negentig. De algehele economische recessie en het ongunstige investeringsklimaat drukten in die jaren zwaar op de resultaten van de sterk conjunctuurgevoelige sector. Daar- 
naast zag de zeer exportafhankelijke sector zich geconfronteerd met felle concurrentie van binnen en buiten de Europese Unie. Na het vallen van "de muur" overspoelden goedkope concurrenten uit de Oost-Europese landen de wereldmarkt. Maar al ver daarvoor was er al sprake van een verslechtering van de Europese exportpositie op de wereldmarkt (AMOA, 1995; EG, 1993; RABO, 1994/1995). In de afgelopen twee jaren profiteerde de branche echter fors van het economisch herstel. In 1994 wist de branche een graantje mee te pikken van de algehele groei van de wereldhandel. De metalektro-ondernemers, die bijna de helft van hun omzet op buitenlandse markten behalen, wisten in dat jaar een produktiegroei van $3,5 \%$ te realiseren. In 1995 zorgden de aantrekkende investeringen voor een grote stroom van orders voor de metalektro-sector, waardoor de produktie stijgt met $5,3 \%$. In 1996 houdt de groei van de exporten naar verwachting onverminderd aan. Daarentegen vlakt de groei van de investeringen waarschijnlijk iets af. De produktie in de metalektro-sector blijft daardoor groeien, zij het in een iets lager tempo (CPB, 1995).

Figuur 1.3

Produktie-, produktiviteits- en werkgelegenheidsontwikkeling in de metaal- en elektrotechnische industrie, 1993-'96

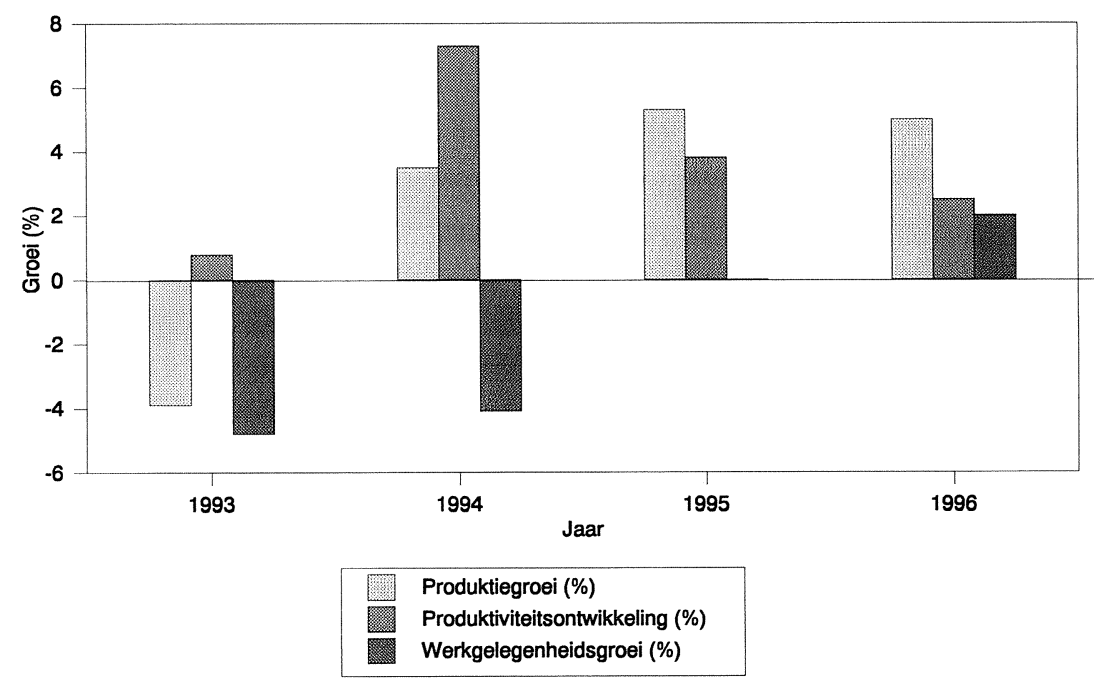

Bron: $\mathrm{CPB}$

Naast de afzetmarktontwikkelingen worden de werkgelegenheidsontwikkelingen in de metalektro-sector ook voor een belangrijk deel beinvloed door de produktiviteitswinsten die worden geboekt. De economische recessie en het inzetten van het eco- 
nomisch herstel gingen gepaard met omvangrijke saneringsoperaties. Veel ondernemingen trokken zich terug op hun kernactiviteiten, om zich te specialiseren op nauw afgebakende niche-markten. Activiteiten, die niet behoren tot de kernactiviteiten worden afgestoten naar toeleveranciers, veelal buiten de metalektro-sector. Mede hierdoor wordt de werkgelegenheidsdaling in de sector pas in 1995 tot staan gebracht. Vanaf 1996 zal er naar verwachting weer sprake zijn van groei. Na 1996 zal die groei waarschijnlijk aanhouden, zij het in een iets lager tempo (CPB, 1995).

\section{Structurele achtergronden}

De teruggang van de werkgelegenheid in de metalektro-sector kan worden geïnterpreteerd tegen de achtergrond van de conjunctuurgevoeligheid van de sector de intersectorale relaties en de organisatie van de produktie.

\section{Conjunctuurgevoeligheid}

De ongunstige ontwikkelingen in de metalektro-sector kunnen worden bezien tegen de achtergrond van het conjunctuurgevoelige karakter van de activiteiten in de sector. Dit hangt vooral samen met het conjunctuurgevoeligheid van de omzet. Een bron van conjunctuurgevoeligheid is het grote exportaandeel in de omzet $(48 \%)$. In de elektrotechnische industrie is deze conjunctuurgevoelige bron van inkomsten zelfs goed voor drie kwart van de omzet. Buiten de metalektro-sector wordt alleen in de chemie een groter exportaandeel behaald. Een tweede bron van conjunctuurgevoeligheid is het grote aandeel van de produktie van investeringsgoederen in de omzet. Binnen de metalektro-sector is met name de machine-industrie afhankelijk van deze omzetcomponent. De intermediaire leveringen zijn eveneens conjunctuurgevoelig: conjuncturele tegenslag wordt in eerste instantie afgewenteld op de toeleveranciers. Vooral vanuit de bouw, de chemie en de overige industrie wordt veel werk uitbesteed aan de metalektro-sector. In de metaalproduktenindustrie zijn de intermediaire leveringen zelfs goed voor bijna de helft van de omzet (ERBO, 1995; RABO, 1995).

\section{Intersectorale inbedding}

Door het grote aandeel van intermediaire leveringen in de omzet is de metalektro erg gevoelig voor de economische ontwikkeling in de omliggende sectoren. Om die reden zal worden aangegeven op welke wijze de sector in de economie is ingebed, toegespitst op de grootste en snelst groeiende intermediaire leveringen.

De bouwsector is de grootste afnemer van produkten uit de metaal- en elektrotechnische industrie. Geleverd worden vooral staalconstructies, onderdelen en lichte produktiemiddelen. Van de bouw ging de afgelopen jaren geen sterke groei-impuls 
uit. Het economische herstel in deze sector trad pas laat in en zwakte al vroeg weer af. Naast de bouw is ook de chemie een belangrijke afnemer van produkten uit de metalektro-industrie. Economische recessies laten zich in de chemie doorgaans sterk voelen. Ook de metalektro ondervindt hiervan de gevolgen. Hoewel de goederenstroom niet omvangrijk is, kenmerkt de relatie met het landbouw en voedingscluster zich door een grote technologische dynamiek. Met name de landbouwmachine-industrie zorgt voor een aanzienlijke goederenstroom tussen beide sectoren. Door de moeizame situatie in de landbouw kan ook van deze sector geen grote orderstroom verwacht worden (Kuijper en van Duren, 1995; CPB, 1995).

Het snel groeiende multimedia en commerciële dienstencluster is voor de metalektro van steeds groter belang. Als gevolg van technologische ontwikkelingen en de liberalisering van de wereldmarkt groeperen bedrijven in de computerindustrie, de consumentenelektronica (beiden metalektro), de telecommunicatie, de media en de amusementsindustrie zich, om zich bezig te gaan houden met het aanbieden van netwerkinfrastructuren, randapparatuur en multimedia-informatie. Ontwikkelingen in de multimedia-markten kunnen voor grote metalektro-ondernemingen niet alleen een enorme impuls zijn, zij zullen ook de metamorfose van de branche inluiden. Veel meer dan voorheen zal het de geproduceerde output het karakter krijgen van een "dienst" (Jacobs en De Man, 1995; Kuijpers en Van Duren, 1995).

Flexibele specialisatie en uitbesteding

De teruggang in werkgelegenheid in de metalektro-sector kan ook worden geïnterpreteerd in het licht van de sterke tendens tot uitbesteding van de werkzaamheden, die buiten de kernactiviteiten vallen.

Nieuwe technologieën volgen elkaar in steeds hoger tempo op, produkt-levenscycli worden steeds korter, fabricage-systemen dienen steeds sneller aangepast te worden aan de veranderde voorkeuren in de markt. Steeds vaker leidt deze turbulentie tot het afstoten van activiteiten. Ondernemingen trekken zich terug op hun kernactiviteiten, om zich te specialiseren in beter afgebakende produktniches (Kuijper en Van Duren, 1995). De uitbestedingstendens zorgt voor groeiende afhankelijkheden tussen de diverse bedrijven binnen de sector. Rondom hoofdaannemers en "mainsuppliers" ontstaan netwerken van onderaannemers en "jobbers", die componenten aanleveren. Aan het ontstaan van intensieve samenwerkingsrelaties tussen gespecialiseerde en flexibel fabricerende ondernemingen wordt ook wel gerefereerd met de term "flexibele specialisatie" (Piore en Sabel, 1987).

De uitbesteding van werkzaamheden door de metalektro-sector brengt een verschuiving van werkgelegenheid met zich mee, veelal naar de meer dienstverlenende sectoren van de economie. Cateraars, beveiligingsbureaus, maar ook uitzend- 
organisaties en detacheringsbureaus verzorgen een steeds groter deel van de werkzaamheden binnen het metaal- of elektrotechnische bedrijf. Het verlies van werkgelegenheid in de metalektro is dus voor een deel terug te voeren op een verplaatsing van die werkgelegenheid naar andere sectoren.

\subsection{Achtergronden per bedrijfsklasse}

In deze paragraaf zal dieper worden ingegaan op de ontwikkelingen binnen de diverse bedrijfsklassen in de metaal- en elektrotechnische industrie. Aan de orde komen de basismetaal, de metaalproduktenindustrie, de machine-industrie, de elektrotechnische industrie en de transportmiddelenindustrie. Bedrijfsklassen die in Zuid-Limburg nauwelijks zijn vertegenwoordigd (zoals de vliegtuigbouw en scheepsbouw) zullen ook in deze landelijke verkenning slechts zijdelings worden belicht. Om een indruk te geven van de onderlinge verhoudingen, is in figuur 1.4 weergegeven hoe de totale produktie en werkgelegenheid in de metaal- en elektrotechnische industrie over de onderscheiden bedrijfsklassen is verdeeld.

Figuur 1.4

Verdeling van de produktie en de werkgelegenheid over de bedrijfsklassen
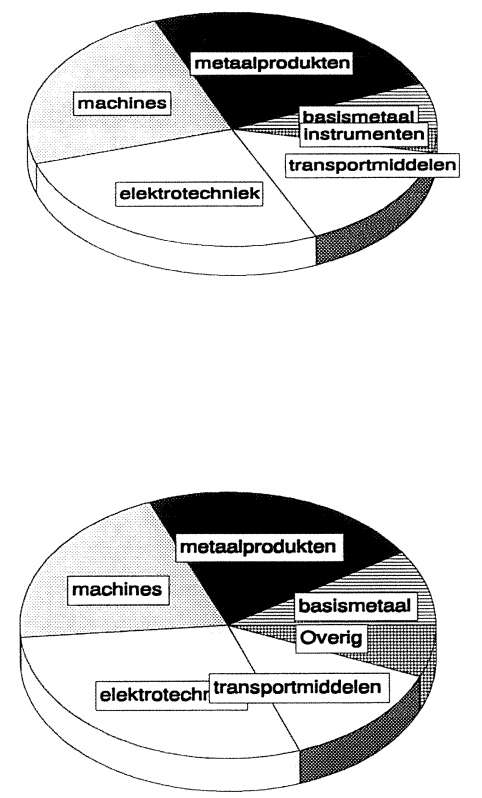

Bron: $\mathrm{CPB}$ 


\section{Basismetaalindustrie}

Door saneringen viel de werkgelegenheid in de basismetaal enorm terug. Van alle branches die door het CPB worden onderscheiden, daalde de werkgelegenheid in de basismetaal in de afgelopen jaren zelfs het snelst. Het keerpunt in de werkgelegenheidsontwikkeling lijkt, ondanks een vroeg en fors herstel van de produktie in 1995, nog niet bereikt (zie figuur 1.5).

De basismetaal bevindt zich aan het begin van de industriële produktieketen. Daardoor kan de branche vaak al vroeg profiteren van een conjunctureel herstel. Op de binnenlandse markt vervult de sector een belangrijke rol als leverancier van halffabrikaten aan industrie en bouw. Daarnaast zet de Nederlandse basismetaal een groot deel van de halffabrikaten af in het buitenland.

Figuur 1.5

Produktie- en werkgelegenheidsontwikkeling in de basismetaalindustrie, 1993-'95

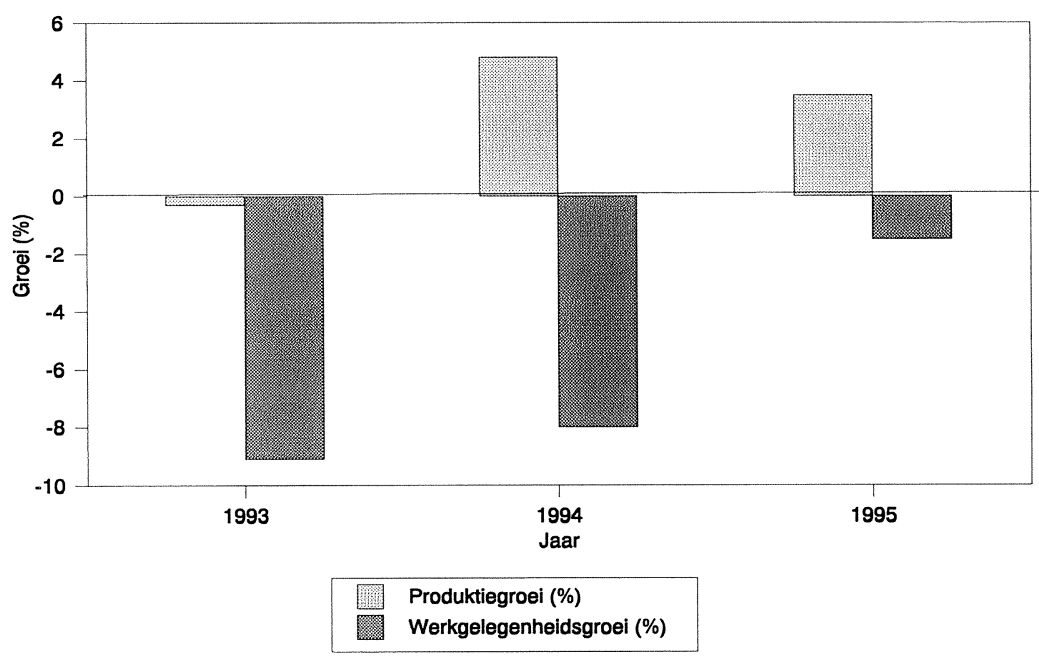

Bron: CPB

Al in 1993 kon door de basismetaalindustrie een voorschot worden genomen op de aantrekkende exporten. De groeiende verkopen in het buitenland konden de slechte gang van zaken op de binnenlandse afzetmarkt - een afzetdaling van $10 \%$ - bijna compenseren. Uiteindelijk daalde de afzet in 1993 in geringe mate. De doorzettende groei van de exporten zorgde in 1994 echter voor een forse afzettoename, die in 1995 iets afvlakte (AMOA, 1995). 
Hoewel de basismetaalindustrie slechts een gering deel van de metalektro-werkgelegenheid omvat (nog geen 7\%), neemt zij een groot deel van het banenverlies in de metalektro-sector voor haar rekening. Op rigoreuze wijze trokken veel bedrijven in de basismetaal zich terug op hun kernactiviteiten. Hoogovens bracht duizenden arbeidsplaatsen onder bij toeleveranciers in andere sectoren. Al in 1993 leidde dit bij dit bedrijf tot een reductie van het arbeidsvolume met 2.500 arbeidsjaren, hetgeen neerkomt op een daling van $10 \%$. De aantrekkende produktie kon niet voorkomen, dat in 1994 een inkrimping van nog eens 2.000 arbeidsjaren plaatsvond (een krimp van $8 \%$ ). Ook 1995 kenmerkt zich door een verdere daling van het arbeidsvolume met 300 arbeidsjaren, ofwel $1,5 \%$. Het is de vraag of deze daling van de werkgelegenheid in 1996, meer dan een jaar nadat het herstel van de landelijke werkgelegenheid intrad, tot staan kan worden gebracht.

\section{Metaalproduktenindustrie}

Ook de metaalproduktenindustrie behoort tot de sectoren, waarbinnen in de eerste helft van de jaren negentig de grootste saneringen zijn doorgevoerd. Het economisch herstel in 1994 en 1995 is niet krachtig genoeg geweest om de inkrimping van de werkgelegenheid al in 1995 te keren (zie figuur 1.6).

De metaalproduktenindustrie is zeer divers van samenstelling. Met behulp van sterk uiteenlopende produktieprocessen wordt gewerkt aan een veelheid van halffabrikaten en onderdelen. Behalve constructiewerkplaatsen en gieterijen horen bijvoorbeeld ook smederijen en oppervlaktewaterbedrijven tot deze branche. De metaalproduktenindustrie speelt een belangrijke rol als toeleverancier van bedrijven in de bouw en de industrie. Daarentegen is de branche minder dan andere bedrijfsklassen binnen de metalektro-sector afhankelijk van de export. "Slechts" 36\% van de omzet wordt in het buitenland gerealiseerd (RABO, 1994/1995; ERBO, 1995).

De branche heeft zwaar te lijden gehad onder de recessie in de eerste helft van de jaren negentig. In 1993, toen de produkttie met $5 \%$ afnam, werd een dieptepunt bereikt. Niet alleen op de binnenlandse markt viel de omzet tegen, ook op de buitenlandse markten werd slecht verkocht. Met de toetreding van nieuwe concurrenten uit Oost-Europa werd de spoeling dunner en de druk op de prijzen hoger (RABO, 1994). In 1994 herstelt de export zich en wordt weer een forse produktiegroei gerealiseerd. In 1995 kan de metaalproduktenindustrie daarnaast ook profiteren van de toegenomen bedrijvigheid in de Nederlandse bouw en industrie. De druk op de prijzen blijft bestaan. Alleen de producenten die belangrijke kennis hebben weten te incorporeren, ontkomen aan de prijsconcurrentie (RABO, 1995).

Ook binnen de metaalproduktenindustrie ging het economisch herstel gepaard met forse reorganisaties en een terugtrekking op de kernactiviteiten. Na de recessie, die 
in 1993 gepaard ging met een banenverlies van 8.000 arbeidsjaren $(-8 \%)$, kromp de werkgelegenheid in 1994 opnieuw met 3000 arbeidsjaren. Zelfs in 1995 was de produktiegroei nog te laag om een werkgelegenheidsdaling te voorkomen: naar verwachting is er sprake van een banenverlies van 500 arbeidsjaren $(-0,8 \%)$. Onzeker is of de produktiegroei in 1996 wel voldoende zal zijn om een toename van de werkgelegenheid te bewerkstelligen (CPB, 1995).

Figuur 1.6

Produktie- en werkgelegenheidsontwikkeling in de metaalproduktenindustrie, 1993-'95

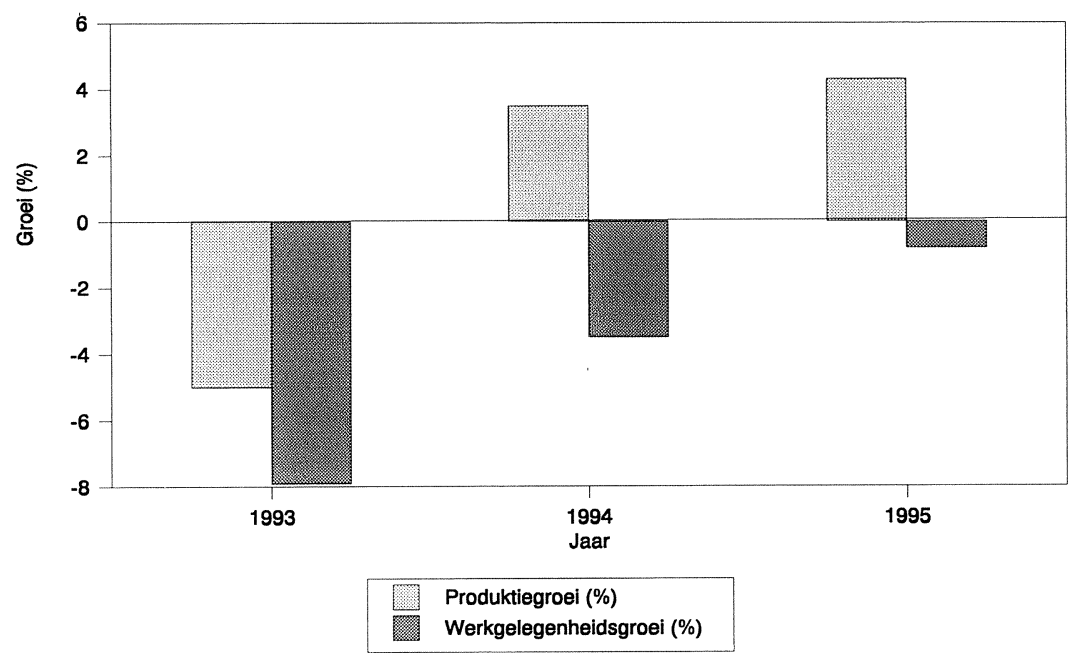

Bron: $\mathrm{CPB}$

\section{Machine-industrie}

Hoewel ook binnen de machine-industrie de werkgelegenheidsreducties in de afgelopen jaren aanzienlijk zijn geweest, onderscheidt de branche zich gunstig van de overige metalektro-sectoren. De werkgelegenheid in de machine-industrie herstelt zich zelfs eerder dan in veel andere bedrijfsklassen. Reeds in 1995 is er sprake van een groei van de werkgelegenheid. Het aanvankelijk aarzelende, maar later overtuigend op gang komend herstel van de investeringen is hieraan debet (zie figuur 1.7).

De machine-industrie is erg afhankelijk van de investeringen van andere bedrijven. De branche drijft daarbij voor bijna de helft op buitenlandse afzetmarkten. De binnenlandse afzetmarkten zijn echter zeer bepalend geweest voor de positie die de branche zich heeft verworven. Het intensieve karakter van de Nederlandse landbouw verschafte de fabrikanten van landbouwmachines een enorme voorsprong op de wereldmarkt. Ook de aanwezigheid van een sterke binnenlandse baggerindustrie 
legde de Nederlandse machinebouwers geen windeieren; Nederlandse machinebouwers hebben zich op dit marktsegment ontwikkeld tot wereldmarktleiders. Ook de binnenlandse aandacht voor milieuproblematiek en de reiniging van verontreinigde grond heeft Nederlandse machinebouwers in de kaart gespeeld (RABO, 1994/1995, Kuijpers en Van Duren, 1987).

Figuur 1.7

Produktie- en werkgelegenheidsontwikkeling in de machine-industrie, 1993-'96

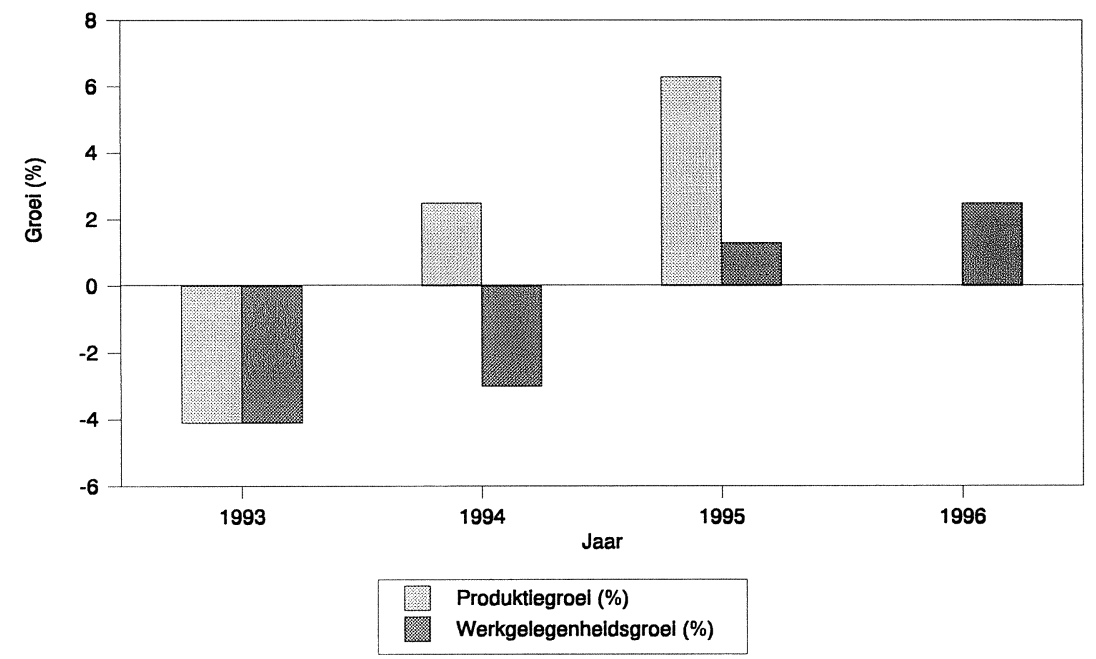

Bron: CPB

De zeer conjunctuurgevoelige machine-industrie heeft een zeer moeilijke periode achter zich. Tijdens de recessie daalde de produktie met meer dan 4\%. In 1994 wist de branche licht te profiteren van de exportgroei. Toch bleef de groei in de machine-industrie achter bij de groeicijfers voor de totale metalektro-sector. In 1995 trekt de produktie onder invloed van de toegenomen landelijke investeringen echter fors aan tot $6,3 \%$ (CPB, 1995).

De saneringsoperaties in de machine-industrie zijn minder omvangrijk geweest dan in de andere metalektro-sectoren. Dat neemt niet weg, dat ook de machine-industrie behoort tot de krimpsectoren. In 1993 en 1994 daalde de werkgelegenheid in de machine-industrie achtereenvolgens met $4.000(-4 \%)$ en 3.000 voltijdsbanen $(-3 \%)$. In 1995 is de saneringsgolf ten einde en herstelt de werkgelegenheid zich als gevolg van de hogere economische groei (+1.000 arbeidsjaren, 1,3\%). In 1996 zal de groei van het aantal banen naar verwachting verdubbelen. Het herstel van de werkgelegenheid in de machine-industrie treedt dus eerder in dan in de andere branches binnen de metalektro-sector, maar vindt plaats na de landelijke kentering in de werkgelegenheidsontwikkeling (CPB, 1995). 


\section{Elektrotechnische industrie}

In de elektrotechnische industrie heeft de werkgelegenheid zich in de afgelopen jaren zeer ongunstig ontwikkeld. Het is aan de relatief gunstige produktie-ontwikkelingen te danken, dat de werkgelegenheid niet nog verder inkromp. Ondanks de forse produktiegroei in 1995, zal er pas in 1996 sprake zijn van een substantiëel herstel van de werkgelegenheid (zie figuur 1.8).

De elektrotechnische industrie bestaat uit de zware elektrotechnische industrie ${ }^{2}$, de industriële installatie en montagebedrijven, en de overige elektrotechnische industrie $^{3}$. De elektrotechnische industrie is sterk afhankelijk van de export: maar liefst drie kwart van de omzet wordt op buitenlandse markten gerealiseerd. Het grootste deel van zowel de produktie als de werkgelegenheid komt voor rekening van het grootbedrijf. Desondanks mag de slagkracht van het midden- en kleinbedrijf in deze bedrijfsklasse niet worden onderschat. Zij bedienen veelal de kleine, maar lucratieve deelmarkten, waarvoor veel marktkennis en know-how vereist is (RABO, 1994).

Figuur 1.8

Produktie- en werkgelegenheidsontwikkeling in de elektrotechnische industrie, 1993-'96

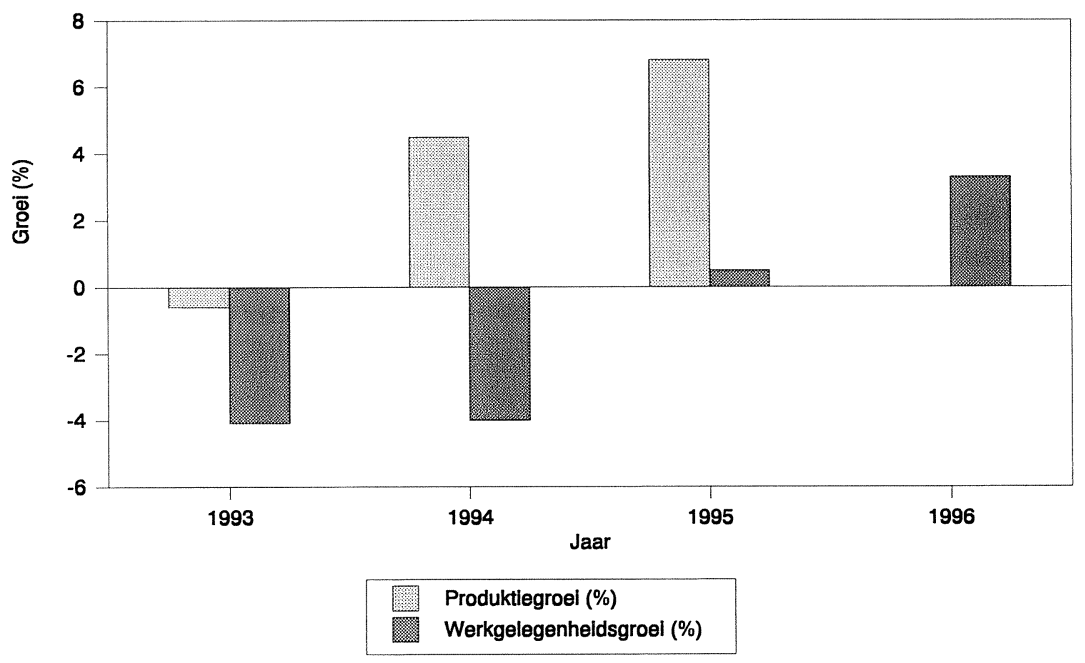

Bron: $\mathrm{CPB}$

2. Draad en kabel, motoren/generatoren/transformatoren, schakel- en instalatiemateriaal.

3. Lampen, telecommunicatie-apparatuur, consumenten-elektronica, halfgeleiders, etc.. 
De elektrotechnische industrie wist volop te profiteren van de aantrekkende exporten. De produktie steeg daardoor in 1994 met $4,5 \%$ en naar verwachting met bijna $7 \%$ in 1995 . Doordat tegelijkertijd op grote schaal werd gereorganiseerd, kon de produktiegroei niet in een substantiële werkgelegenheidsgroei worden omgezet. In 1994 verdwenen per saldo 4.000 full-time banen; in 1995 groeide de werkgelegenheid met slechts 500 voltijds-arbeidsplaatsen. Voor 1996 wordt een meer substantële werkgelegenheidsgroei verwacht van in totaal 3.000 arbeidsjaren.

\section{Transportmiddelenindustrie}

De transportmiddelenindustrie is - tezamen met de basismetaalindustrie - de sterkst gekrompen branche in de Nederlandse economie. Door grootschalige saneringsoperaties in de transportmiddelenindustrie daalde de werkgelegenheid in deze branche in de afgelopen jaren in een ongekend tempo. Het recente faillissement van vliegtuigfabrikant Fokker betekent een nieuwe dreun voor de activiteiten in deze bedrijfsklasse. De auto-industrie lijkt zich na de saneringsoperaties van de afgelopen jaren redelijk te herstellen (zie figuur 1.9).

De transportmiddelenindustrie valt uiteen in de auto-industrie en de overige industrie (waaronder de vliegtuigbouw). De auto-industrie omvat - na de saneringen die de recessie met zich meebracht - nog circa 15\% van de werkgelegenheid in de metalektro-sector. Ook de transportmiddelenindustrie is voor haar omzet sterk afhankelijk van de ontwikkelingen op de buitenlandse afzetmarkten.

Figuur 1.9

Produktie- en werkgelegenheidsontwikkeling in de transportmiddelenindustrie, 1993-'96

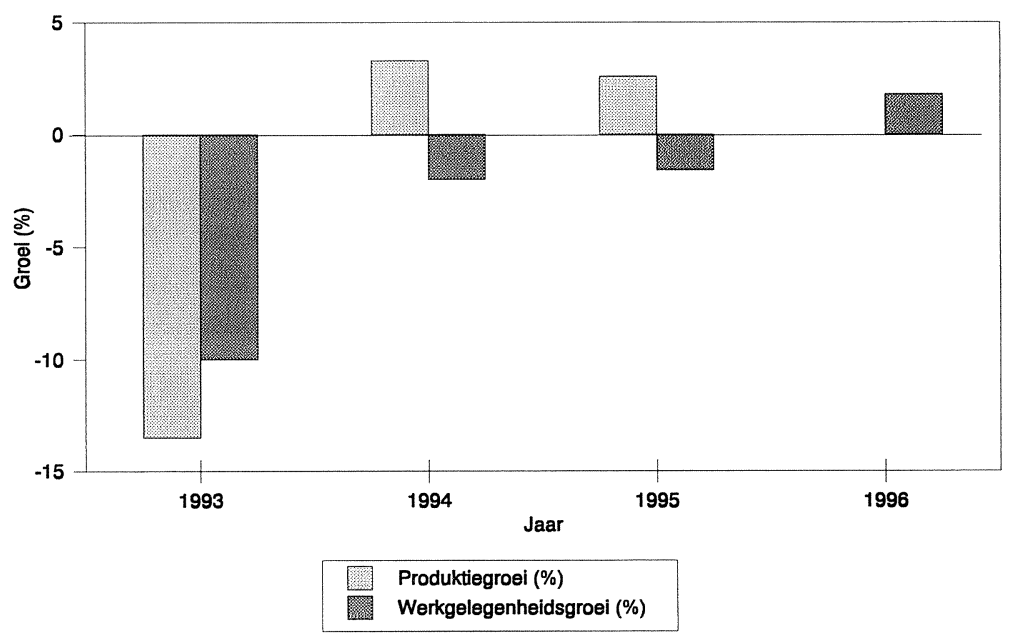

Bron: CPB 
De Nederlandse transportmiddelenindustrie kreeg tijdens de recessie een grote teruggang van de produktie te verwerken; in 1993 viel de afzet terug met $13,5 \%$. Binnen de auto-industrie viel de afzet terug met $15 \%$. Ook in de overige transportmiddelenindustrie werd een grote teruggang geboekt. In 1994 herstelde de autoindustrie zich opmerkelijk goed, met een produktietoename van $9,5 \%$. Bij de overige transportmiddelenindustrie was er daarentegen geen enkele produktietoename. Dit patroon zet zich in 1995 versterkt voort (naar verwachting een produktiegroei van $11,3 \%$ in de auto-industrie, tegenover een faillissement van Fokker).

Parallel aan de wederopbloei van de auto-industrie werden enorme reorganisaties doorgevoerd. Nedcar bracht de produktie onder in één vestiging (Born), besteedde een substantieel deel van de werkzaamheden uit en ging intensieve samenwerkingsverbanden aan met de "main-suppliers". DAF failleerde en ontsloeg het leeuwedeel van het personeelsbestand. De werkgelegenheid bleef daardoor in 1994 nog dalen met 1.000 banen, hetgeen een daling van 4,5\% betekende. In 1995 wordt een stijging van de werkgelegenheid met 500 arbeidsjaren verwacht. In de overige transportmiddelenindustrie houdt het verlies aan werkgelegenheid onverminderd aan. Exemplarisch voor de situatie in deze branche is de gang van zaken bij Fokker. Reorganisaties in samenhang met teruglopende afzetcijfers zorgen voor een inkrimping van de werkgelegenheid. 


\section{Bedrijven in de Zuid-Limburgse metaal-en elektrotechnische industrie}

In dit hoofdstuk wordt de verkenning toegespitst op de regio Zuid-Limburg. De opbouw van het hoofdstuk is vergelijkbaar met die van hoofdstuk 1 . Eerst zal in paragraaf 2.1 de Zuid-Limburgse metalektro-sector worden gepositioneerd ten opzichte van de andere bedrijfssectoren. In paragraaf 2.2 zullen de achtergronden van de werkgelegenheidsontwikkelingen nader worden belicht. In paragraaf 2.3 zullen de ontwikkelingen en perspectieven per bedrijfsklasse worden beschreven. De belangrijkste cijfers zijn afkomstig uit de regionale arbeidsmarktprognoses van het Landelijk Bureau voor de Arbeidsvoorziening. Deze prognoses zijn op te vatten als een regionale verbijzondering van de voorspellingen van het Centraal Planbureau, die in het eerste hoofdstuk centraal stonden. Voor diverse bedrijfsklassen binnen de metaal- en elektrotechnische industrie is een beeld te schetsen van de ontwikkelingen tot en met 1996.

\subsection{Ontwikkeling van de regionale werkgelegenheid}

De ontwikkeling van de regionale metaal- en elektrotechnische industrie weerspiegelt voor een belangrijk deel de landelijke gang van zaken in deze sector. Desondanks kent de regio haar eigen economische structuur en dynamiek. Om recht te doen aan die regio-specifieke context, zal in beeld worden gebracht hoe de diverse sectoren zich tot elkaar en tot de landelijke situatie verhouden.

Figuur 2.1 geeft een overzicht van het regionale specialisatiepatroon op basis van het aandeel in de totale werkgelegenheid en de groei van de werkgelegenheid in de desbetreffende sector. Als maatstaf voor het aandeel in de werkgelegenheid wordt hier de nadruk gelegd op de regio-specifieke oververtegenwoordiging in de werkgelegenheid. De werkgelegenheidsgroei heeft betrekking op de regionale meergroei van de werkgelegenheid: de mate waarin een sector in de regio sneller groeit dan landelijk. De diverse sectoren zijn gepositioneerd binnen de vier kwadranten, waarmee hun positie ten opzichte van de landelijke situatie in beeld wordt gebracht.

In vak 1 bevinden zich vooral de commerciële en niet-commerciële diensten. Hoewel deze sectoren in Zuid-Limburg zijn ondervertegenwoordigd, ontwikkelt de werkgelegenheid in deze branches zich in deze regio gunstiger dan landelijk het geval is. Opvallend is, dat geen enkele bedrijfssector in het tweede vak is gesitueerd. Binnen de sectoren die in Zuid-Limburg zijn oververtegenwoordigd, ontwikkelt de werkgelegenheid zich kennelijk nergens gunstiger dan landelijk het geval is. Ook het derde vak is mager gevuld. Slechts binnen enkele ondervertegenwoordigde sectoren, waaronder de machine-industrie, blijft de werkgelegenheidsontwikkeling 
achter bij de landelijke groei. In vak 4 bevinden zich vooral industriële sectoren, die in Zuid-Limburg veelal zijn oververtegenwoordigd. De werkgelegenheid in deze industrieën ontwikkelt zich ongunstiger dan landelijk het geval is.

De Zuidlimburgse metalektro-sector is te positioneren als een licht oververtegenwoordigde sector, die zich iets ongunstiger ontwikkelt dan landelijk het geval is. Van alle bedrijfsklassen binnen de metalektro is de transportmiddelenindustrie het zwaarst oververtegenwoordigd, vanwege de vestiging van NedCar en de daaraan toeleverende bedrijven. De machine-industrie is daarentegen duidelijk ondervertegenwoordigd in Zuid-Limburg. Ook de regionale werkgelegenheidsontwikkeling steekt zich ongunstig af ten opzichte van de landelijke ontwikkeling in deze bedrijfsklasse. De andere bedrijfsklassen binnen de metalektro zijn in Zuid-Limburg naar evenredigheid vertegenwoordigd. De basismetaal- en metaalproduktenindustrie is daarbij de enige branche binnen de metalektro-sector waar de werkgelegenheidsontwikkeling in Zuid-Limburg gunstig afsteekt bij de landelijke ontwikkeling.

Figuur 2.1

Regionaal werkgelegenheidsgroei en -specialisatiepatroon Zuid-Limburg

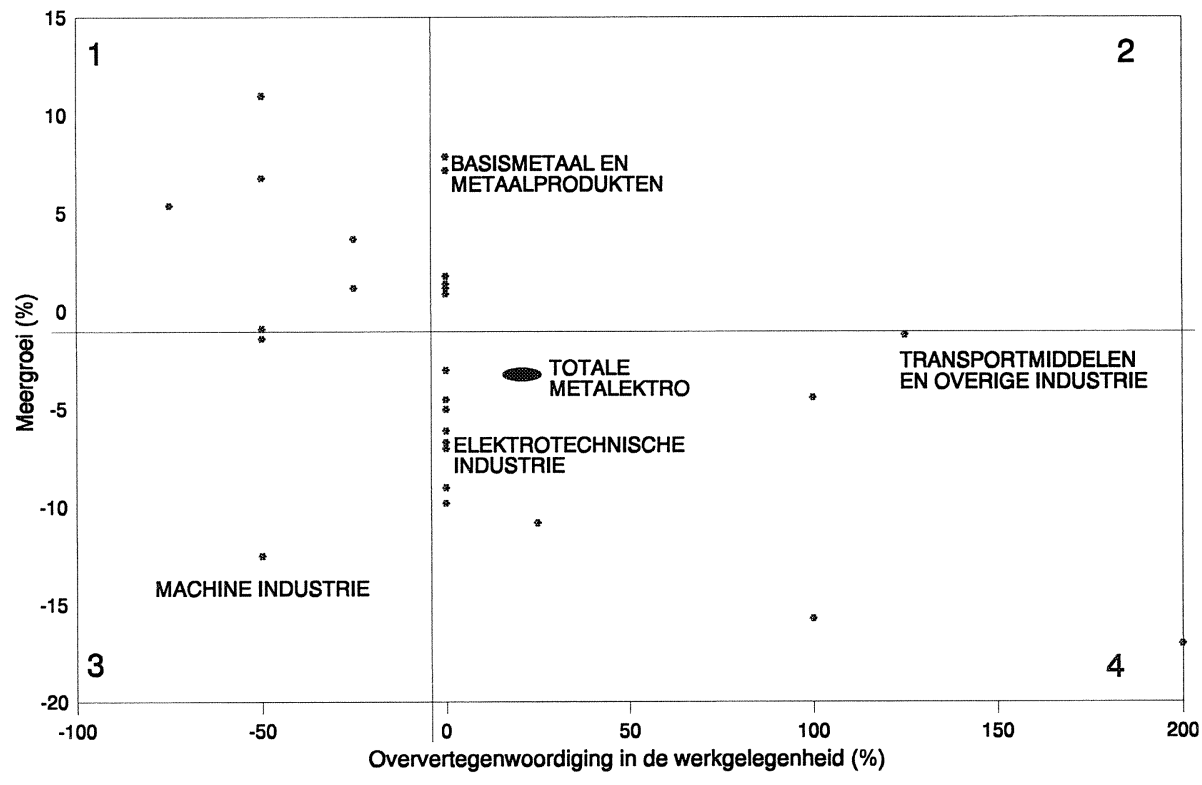

Bron: LBA 


\subsection{Achtergronden van de werkgelegenheidsontwikkelingen}

In deze paragraaf worden de achtergronden van de ongunstige werkgelegenheidsontwikkelingen in de Zuid-Limburgse metaal- en elektrotechnische industrie geschetst. In paragraaf 2.2 worden de werkgelegenheidsontwikkelingen gerelateerd aan de afzetmarktontwikkelingen.

\section{Afzetmarktontwikkelingen}

Vooral door een sterke groei van de exporten herstellen de afzetmarkten van de Zuid-Limburgse metalektro-sector zich duidelijker dan landelijk het geval is. De werkgelegenheid blijt naar verwachting echter achter bij het herstel van de afzetmarkten. Volgens de voorspellingen van het Landelijk Bureau Arbeidsvoorziening leidt dit vooralsnog niet tot een gunstiger ontwikkeling van de werkgelegenheid (zie figuur 2.2).

De negatieve werkgelegenheidsontwikkelingen in de afgelopen jaren zijn voor een belangrijk deel terug te voeren op slechtere afzetmarktontwikkelingen. De omzetten in de metaal- en elektrotechnische industrie in de regio daalden in 1993 sterker dan landelijk het geval was. Duidelijk is aan de indexcijfers te zien dat de afzetmarkten zich in 1994 herstelden. Dankzij een enorme stijging van de exporten lieten de regionale metalektro ondernemers hun landelijke collega's ver achter zich $(11 \%$ regionale omzetgroei, tegen $3 \%$ landelijk). De metalektro-sector werd daarmee niet alleen een van de snelst groeiende sectoren in Zuid-Limburg, ook het verschil met de landelijk ontwikkeling was groter dan in de andere bedrijfssectoren, met uitzondering van de chemie (ERBO, 1995).

Ondanks de positievere ontwikkeling op de afzetmarkten daalde de werkgelegenheid in de Zuid-Limburgse metalektro-sector in 1994 wel. Volgens het Landelijke Bureau Arbeidsvoorziening (LBA) daalde de werkgelegenheid in Zuid-Limburg in deze sector zelfs veel forser dan landelijk het geval was. Hieruit zou kunnen worden afgeleid dat de saneringsoperaties in de metalektro-sector in Zuid-Limburg nog ingrijpender zijn geweest dan de landelijke afslankingen. Het patroon waarlangs de werkgelegenheid in de regio zich in de komende jaren zal ontwikkelen, is volgens de LBA vergelijkbaar met het landelijk patroon: herstel vanaf 1996 met een groei van $2 \%$. Daarna zal dit groeitempo afzwakken. Overigens zijn er ook optimistischer scenario's dan die van het LBA. Deze scenario's (van het ETIL) voorzien dat de banengroei in de metalektro-sector eerder en forser zal intreden. 


\section{Structurele achtergronden}

Ook in Zuid-Limburg zijn de werkgelegenheidsontwikkelingen in de metalektro niet los te zien van de "inbedding" in de regionale economie en de structuur van de sector zelf. De regionale sectorale relaties wijken in een aantal opzichten af van het landelijk beeld. Hieronder komen de belangrijkste verschillen aan bod.

\section{Conjunctuurgevoeligheid}

Uit de ERBO-enquête blijkt, dat Zuid-Limburgse metalektro-ondernemers - evenals de Zuid-Limburgse ondernemers in andere bedrijfstakken - aanzienlijk exportgerichter zijn dan hun landelijke collega's. Maar liefst $60 \%$ van de metalektro-omzet wordt in het buitenland gerealiseerd. Landelijk blijft het exportaandeel in de omzet lager dan $50 \%$. De Zuid-Limburgse ondernemingen in de metalektro-sector exporteren echter niet alleen een groter deel van hun produktie, hun exportwaarde groeit ook sneller dan landelijk het geval is. In 1994 bedroeg de groei van de exportwaarde niet twee, maar vier keer de landelijke groei (ERBO, 1995).

\section{Intersectorale inbedding}

De chemische sector is in de regio Zuid-Limburg veel groter dan landelijk het geval is. Vooral de aanwezigheid van DSM is hieraan vanzelfsprekend debet. De metalektro-sector in Zuid-Limburg profiteert sterk van de aanwezigheid van de zeer conjunctuurgevoelige chemische sector. De metalektro-sector fabriceert en onderhoudt pijpleidingsystemen, procesbehuizing, opslagtanks en reservoirs. De afhankelijkheid van de zeer conjunctuurgevoelige chemische industrie heeft echter ook zijn schaduwzijde. Tijdens de recessie werd door de chemie vooral bezuinigd op niet direct noodzakelijke onderhoudswerkzaamheden. Volgens consulenten van de arbeidsbureaus werd daardoor de toch al conjunctuurgevoelige metalektro-industrie in deze regio extra zwaar getroffen. De opleving van de chemie kan daarentegen een enorme impuls zijn voor de toeleveranciers in de metalektro-sector.

Naast de chemische industrie, bepaalt ook de sterk oververtegenwoordigde transportmiddelensector in belangrijke mate de ontwikkelingen in de branche. Rondom de autofabrikant Nedcar heeft zich een uitgebreid netwerk van toeleveranciers gevestigd, veelal behorend tot de metalektro-sector. De ontwikkelingen op de automarkt zijn dan ook zeer bepalend voor de gang van zaken in de Zuid-Limburgse metalektro.

De regionale ontwikkeling van de (ook in hoofdstuk 1 genoemde) multimedia-activiteiten, neemt een grote vlucht. In een onlangs verschenen rapport wordt deze sector door het LIOF (1995) aangeprezen als de reizende ster in de Limburgse eco- 
nomische structuur. De vestiging van het telecommunicatiebedrijf Libertel is inmiddels een feit.

Flexibele specialisatie en uitbesteding

Zuid-Limburg kent een aantal intensieve toeleveringsnetwerken waarin metalektroondernemingen een cruciale rol spelen. Rondom de vestiging van Nedcar heeft zich een groot netwerk van toeleveranciers gevormd. De indirecte, toeleverende werkgelegenheid is veel groter dan de werkgelegenheid binnen het Nedcar-concern zelf. Ook in het toeleveringsnetwerk dat zich rondom DSM heeft gevestigd speelt de metalektro-sector een cruciale rol.

\subsection{Achtergronden per bedrijfsklasse}

In deze paragraaf zal dieper worden ingegaan op de ontwikkelingen binnen de diverse bedrijfsklassen in de Zuid-Limburgse metaal- en elektrotechnische industrie. Aan de orde komen de basismetaal en de metaalproduktenindustrie, de machineindustrie, de elektrotechnische industrie en de transportmiddelenindustrie.

\section{Zuid-Limburgse basismetaal en metaalproduktenindustrie}

De werkgelegenheid in de basismetaal en de metaalproduktenindustrie ontwikkelt zich volgens de prognoses conform het landelijk beeld.

Zoals ook uit figuur 2.1 bleek, heeft de werkgelegenheid in de bedrijfsklasse basismetaal en metaalproduktenindustrie zich redelijk gunstig ontwikkeld. Niet alleen was de teruggang van de werkgelegenheid minder groot dan landelijk het geval was (in 1993 was er zelfs sprake van een stijging), ook werd het dieptepunt eerder bereikt. Vanaf 1996 lijkt de werkgelegenheid zich weer conform het landelijk beeld te ontwikkelen.

\section{Zuid-Limburgse machine-industrie}

Vanaf 1996 groeit ook in Zuid-Limburg de werkgelegenheid in de machine-industrie. Landelijk was de groei al in 1995 ingetreden.

De afzet voor de in Zuid-Limburg sterk ondervertegenwoordigde machine-industrie ontwikkelde zich veel ongunstiger dan landelijk het geval was. De regionale machinebouw branche heeft veel te lijden gehad van een reductie in het investeringsprogramma van DSM. Dit leidde tot bedrijfssluitingen bij verschillende middelgrote metalektro-onderneming (ETIL, 1994). 
Figuur 2.2

Regionale en landelijke produktie-, export- en werkgelegenheidsontwikkeling in de metalektroindustrie
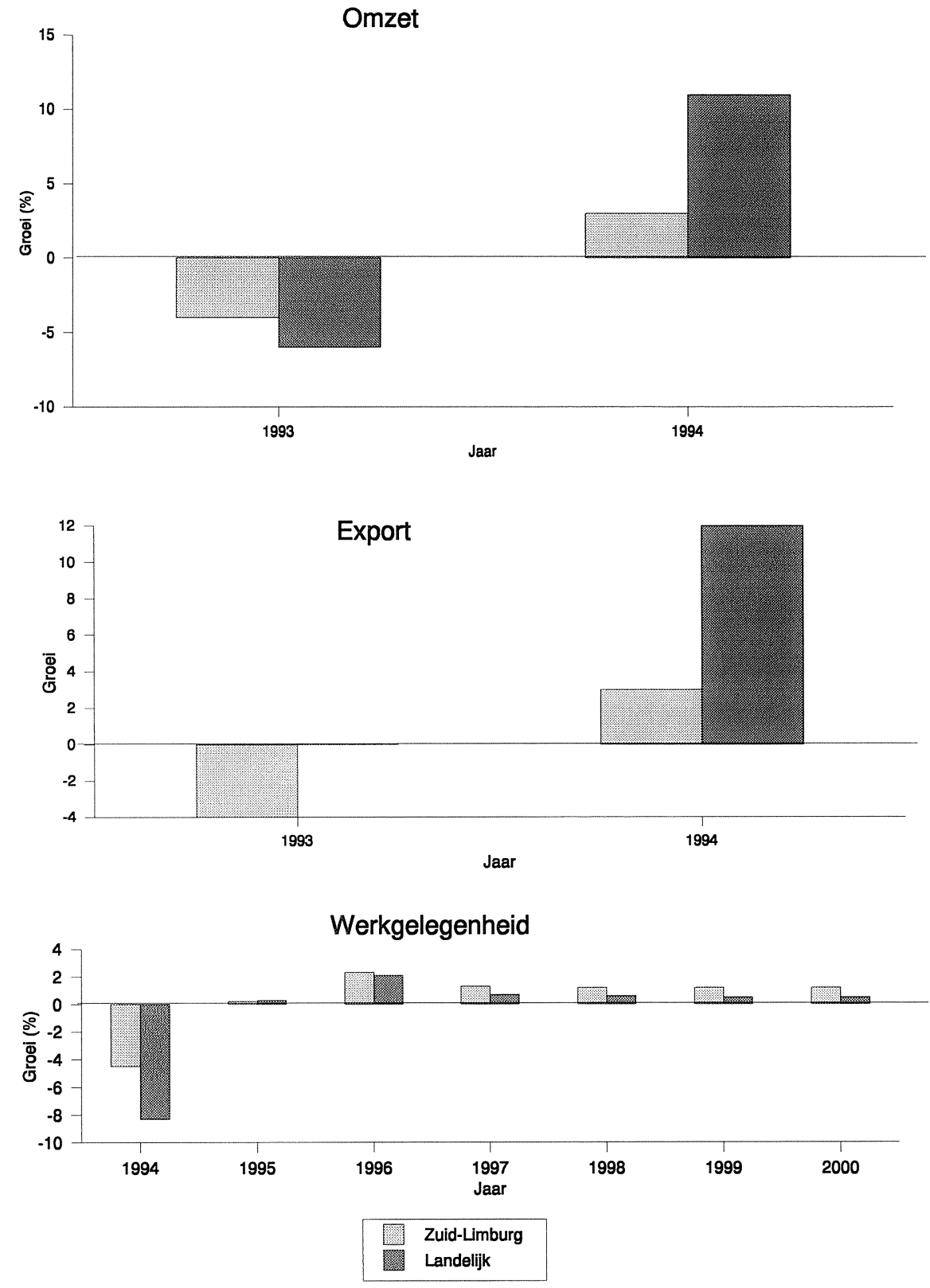

Bron: ERBO, CPB en LBA 
Zoals ook uit figuur 2.1 blijkt, is de afgelopen jaren de regionale werkgelegenheidsontwikkeling binnen de machine-industie minder gunstig geweest dan landelijk. Niet alleen is de daling van de werkgelegenheid groter, het herstel zette ook later in. In 1996 stijgt volgens de prognoses de regionale werkgelegenheid. In dat jaar ontwikkelt de branche zich zelfs gunstiger dan landelijk het geval is (CBA, 1995).

\section{Zuid-Limburgse electrotechnische industrie}

De werkgelegenheid in de elektrotechnische industrie in Zuid-Limburg is de afgelopen jaren in nog sterkere mate gedaald dan landelijk. Inmiddels stijgt de werkgelegenheid weer conform het landelijk patroon.

De afzetmarkten van de elektrotechnische branche in de regio Zuid-Limburg hebben zich zeer verschillend ontwikkeld. Door consulenten wordt melding gemaakt van het faillissement van enkele middelgrote ondernemingen in deze bedrijfsklasse. Anderzijds hebben niet alle elektrotechnische bedrijven geleden onder de recessie. Vele ondernemers in deze branche konden bijvoorbeeld profiteren van de toenemende tendens tot uitbesteding van werkzaamheden door de grote concerns. Onderhoudswerkzaamheden die voorheen werden verricht door de technische dienst van DSM, worden steeds vaker in samenwerking met enkele toeleveranciers verricht.

Het totale aantal banen in de elektrotechnische industrie ging in Zuid-Limburg sneller achteruit dan landelijk het geval was. Vanaf 1995 stijgt het aantal arbeidsplaatsen echter weer. Eerst iets sneller dan landelijk, in 1996 weer conform het landelijk patroon.

\section{Zuid-Limburgse transportmiddelenindustrie}

In Zuid-Limburg kan fors worden geprofiteerd van de stijgende produktie in de autoindustrie. De werkgelegenheid in de transportmiddelenindustrie kan hierdoor een sterke impuls krijgen.

Ook de afzetmarkten van de sterk oververtegenwoordigde transportmiddelenindustrie in deze regio ontwikkelden zich tot 1993 zeer ongunstig. NedCar in Born zag zich gedwongen de produktie terug te brengen met $15 \%$. In 1994 zette echter het herstel van de automarkt in. NedCar realiseerde in dat jaar een produktiegroei van $20 \%$. De onderneming investeerde aanzienlijk in het opzetten van nieuwe produktielijnen voor de Mitshubishi Carisma en de nieuwe Volvo. Parallel aan deze produktiegroei voltrekt zich een verplaatsing van werkzaamheden richting toeleveranciers. Ter illustratie: tussen 1990 en 1993 decimeerde de directe bijdrage van NedCar aan het regionaal produkt, daarentegen steeg de indirecte bijdrage enorm ( $E$ TIL, 1994). 
Naar wordt verwacht herstelt de werkgelegenheid in de regionale transportmiddelenindustrie in Zuid-Limburg zich langzaam. Conform het landelijk patroon voor de transportmiddelenindustrie wordt in 1996 voor het eerst een aanzienlijke groei van het aantal arbeidsplaatsen verwacht. Regionale incidenten kunnen dit beeld fors verstoren. Zo is in de voorspellingen van het LBA niet expliciet rekening gehouden met de groei van de activiteiten in Born. NedCar heeft volgens de consulenten van de Arbeidsbureaus recentelijk weer veel nieuwe arbeidskrachten aangenomen (100 per maand, oplopend tot in totaal 1.000) om met de produktie van de nieuwe modellen te kunnen beginnen. In de regio kan dus fors worden geprofiteerd van de gunstige ontwikkelingen binnen de auto-industrie. 


\section{Beroepen in de metaal- en elektrotechnische industrie}

In dit hoofdstuk wordt nader ingegaan op de belangrijkste beroepen in de metalektro-sector. De aandacht zal daarbij vooral uitgaan naar de technische beroepen. De analyse wordt toegespitst op een viertal vragen.

1. Wat zijn de meest voorkomende (technische) beroepen in de metalektro-sector?

2. Hoe ontwikkelt zich de werkgelegenheid in deze beroepen?

3. Domineert de metalektro-sector de ontwikkeling van de werkgelegenheid in deze beroepen?

4. In welke deelmarkten doen zich knelpunten voor?

Voor zover mogelijk zullen de landelijke antwoorden op de eerste drie hoofdvragen worden verbijzonderd naar de regio Zuid-Limburg. De vierde vraag zal geheel worden toegespitst op de regionale arbeidsmarktsituatie.

\subsection{Arbeidsmarktontwikkelingen per beroep}

Figuur 3.1 geeft een beeld van de arbeidsmarktontwikkelingen voor de belangrijkste technische metalektro-beroepsklassen. Twee dimensies worden onderscheiden:

- Het aantal baanopeningen dat volgens de arbeidsmarktprognoses van het ROA in de periode 1995-2000 zal ontstaan. Deze baanopeningen hebben betrekking op de som van de uitbreidingsvraag en de vervangingsbehoefte.

- Het aandeel van de metalektro-sector in de werkgelegenheid in de desbetreffende beroepsklasse.

Twee lijnen delen de figuur in vier vakken. De verticale lijn ligt langs het punt waarop de metalektro-sector $50 \%$ van de werkgelegenheid in een beroepsklasse voor haar rekening neemt. De horizontale lijn ligt langs het punt waarop het aantal baanopeningen in de periode 1995-2000 zich ontwikkelt conform het landelijk gemiddelde. Door de onderscheiden beroepsklassen over de vier vakken te verdelen, ontstaat een beeld van de mate waarin een beroepsklasse wordt gedomineerd door de metalektro-sector en de verwachte ontwikkeling van het totale aantal baanopeningen in dit beroep. De 10 grootste beroepsklassen in de metalektro-sector zijn in de figuur geordend in volgorde van grootte (tabel 3.1 vermeldt de namen van de beroepsklassen). De regionale "ranking" is anders; deze is in de figuur tussen haakjes aangegeven. 
Figuur 3.1

Verwachte baanopeningen 1995-2000 en marktaandeel metalektro-sector naar beroepsklasse ${ }^{*}$

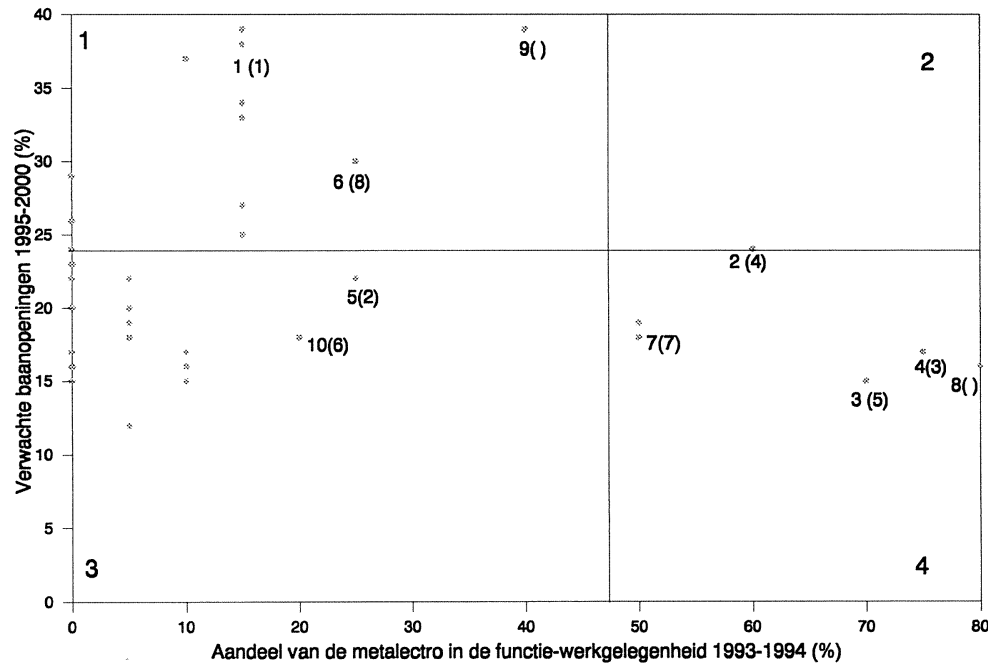

- De beroepsklasse-nummers verwijzen naar de rangorde in tabel 3.1

Bron: ROA/CBS

Binnen de beroepen in het tweede en het vierde vak neemt de metalektro-sector een dominante positie in. De functies in het tweede vak onderscheiden zich daarbij door het grote aantal baanopeningen dat naar verwachting in de komende jaren zal ontstaan. Voor de functies in het vierde vak wordt daarentegen een relatief gering aantal baanopeningen verwacht. Bij de beroepen in het eerste en het derde vak speelt de metalektro geen dominante rol. De functies in het eerste vak onderscheiden zich door het grote aantal baanopeningen dat ontstaat, terwijl in de functies in het derde vak relatief weinig baanopeningen ontstaan.

Tabel 3.1 geeft een overzicht van de qua aantal werkenden belangrijkste technische beroepsklassen in de metalektro-sector. De 10 grootste technische beroepsklassen in de metalektro zijn met elkaar goed voor $60 \%$ van de totale metalektro-werkgelegenheid. Alle technische beroepsklassen tezamen, omvatten $70 \%$ van de totale metalektro-werkgelegenheid. 
Tabel 3.1

Top-10 van technische beroepsklassen in de metalektro in Nederland en Zuid-Limburg, gemiddelden 1993-1994

\begin{tabular}{lllc}
\hline $\begin{array}{l}\text { Rangorde } \\
\text { NL (ZL) }\end{array}$ & Beroepsklassen & Werkzame \\
& & & personen (NL) \\
\hline 1 & $(1)$ & Middenkader functies & \\
2 & $(4)$ & Machinebank- en plaatwerkers en smeden & 47.000 \\
3 & $(5)$ & Lassers, constructeurs en edelsmeden & 43.500 \\
4 & $(3)$ & Metaalbewerkers & 42.000 \\
5 & $(2)$ & Monteurs en controleurs electrotechn. installaties & 25.500 \\
6 & $(8)$ & Instrumentenmakers en onderhoudsmonteurs & 25.000 \\
7 & $(7)$ & Monteurs en controleurs elektrotech produkten & 16.000 \\
8 & $(-)$ & Vakkrachten metaalindustrie & 11.000 \\
9 & $(-)$ & Elektrotechnische constructeurs en ingenieurs & 10.000 \\
10 & $(6)$ & Produktiepersoneel aardewerk- en glasindustrie & 9.000 \\
& &
\end{tabular}

\section{Bron: ROA/CBS}

\section{Landelijke totaalbeeld}

Opvallend is, dat de beroepsklassen waarbij de metalektro als sector domineert zich onderscheiden door het relatief lage aantal baanopeningen dat voor de komende jaren wordt verwacht. Al deze beroepsklassen zijn te vinden in het vierde vak. Het gaat hier om de lassers, constructeurs, edelsmeden, metaalbewerkers, monteurs en controleurs elektrotechnische produkten en vakkrachten metaalindustrie. De drie beroepsklassen waarbinnen de metalektro een minder dominante positie inneemt, hebben daarentegen naar verwachting een relatief hoog aantal baanopeningen. Daarbij gaat het om de middenkaderfuncties, elektrotechnische constructeurs en ingenieurs en instrumentenmakers en onderhoudsmonteurs.

De ontwikkeling van het aantal baanopeningen per beroepsklasse kan beter worden geïnterpreteerd door de samenstellende componenten nader te beschouwen. Om die reden zal hier kort worden ingegaan op de vervangings- en de uitbreidingsvraag. Onder de vervangingsvraag wordt de behoefte aan nieuwkomers verstaan, die voortvloeit uit het vertrek van beroepsbeoefenaren uit de beroepsklasse (in verband met bijvoorbeeld pensionering). Op een enkele uitzondering na, is de vervangingsvraag bij de voor de metalektro-sector belangrijkste beroepsklassen laag tot gemiddeld.

Naast de vervangingsvraag is ook de groei van de werkgelegenheid in een bepaalde beroepsklasse, de zogeheten uitbreidingsvraag, zeer bepalend voor de behoefte aan nieuwkomers op de arbeidsmarkt. De uitbreidingsvraag is te herleiden tot verschuivingen in de beroepenstructuur (beroepseffecten), en de groei van de werkgelegenheid in de sectoren waarin de beroepsbeoefenaren werkzaam zijn (sectoref- 
fecten). De uitbreidingsvraag van de in tabel 3.1 genoemde beroepen is laag (vaak negatief) tot gemiddeld. De verwachte vervangingsvraag is eveneens laag tot gemiddeld. De ongunstige werkgelegenheidsontwikkelingen in de metalektro-sector zijn hieraan mede debet. Uitzonderingen op deze regel zijn de functies waarvoor een relatief hoog opleidingsniveau is vereist (middenkader functies en hogere elektrotechnici).

\section{Regionaal totaalbeeld}

Het relatieve belang van de onderscheiden beroepsklassen in de regio Zuid-Limburg wijkt in een aantal opzichten af van het landelijke beeld. Wanneer wordt gekeken naar de functies die de metalektro-sector werkgelegenheid domineren, treden enkele belangrijke verschillen tussen het landelijke en regionale beeld op de voorgrond. Sterker nog dan landelijk, wordt de metalektro-werkgelegenheid in Zuid-Limburg gedomineerd door de vaktechnische functies. Het aandeel van deze functies in de totale metalektro-werkgelegenheid loopt op tot boven de $75 \%$, hetgeen significant meer is dan het landelijk aandeel van $70 \%$.

Uit tabel 3.1 blijkt dat de 'ranking' van de beroepsklassen in Zuid-Limburg op enkele punten significant verschilt van het landelijk beeld. Opvallend is de hoge klassering van de monteurs en controleurs van elektrotechnische installaties in Zuid-Limburg (landelijk op 5 , in de regio op een gedeelde $2 \mathrm{e}$ plaats). De Machinebankwerkers daarentegen staan in de regio erg laag genoteerd (landelijk op de tweede, regionaal op de vijfde plaats).

Ten slotte kan ook het aantal baanopeningen dat in de regio ontstaat, afwijken van het aantal banen dat landelijk komt open te staan ${ }^{4}$. Zo wordt de vervangingsvraag positief beïnvloed door de sterke vergrijzing van de werkende beroepsbevolking. Deze ontwikkeling is in Zuid-Limburg verder voortgeschreden dan elders. Meer dan een kwart van de werkzame beroepsbevolking in Zuid-Limburg is tussen de 45 en de 65 jaar oud. Landelijk bevindt zich slechts een op de vijf personen in deze leeftijdscategorie (CBS, 1994). Op basis hiervan mag verwacht worden dat de regionale vervangingsvraag groter zal zijn dan het landelijk beeld doet vermoeden.

Ook de regionale uitbreidingsvraag kan afwijken van het landelijke beeld. In dit kader lijkt vooral een nadere analyse van de regionale sectoreffecten van groot belang. Wanneer alleen naar de sectoreffecten wordt gekeken - zoals in de beroepenprognoses van het LBA - blijkt dat de uitbreidingsvraag in Zuid-Limburg in bijna alle beroepsklassen achterblijft op de landelijke uitbreidingsvraag. Dit geldt ook voor

4. Helaas zijn dergelijke regionale prognoses vooralsnog niet beschikbaar. 
de technische beroepen, die in de metalektro goed vertegenwoordigd zijn. De achterblijvende groei van de regionale werkgelegenheid in de metalektro-sector (zie paragraaf 2.3) is hieraan debet.

\subsection{Landelijke en regionale ontwikkelingen per beroepsklasse}

In deze paragraaf zal dieper worden ingegaan op de kenmerken van en ontwikkelingen binnen de belangrijkste beroepsklassen in de metalelectro-sector en de verwachte vraagontwikkelingen. Een schets van de landelijke ontwikkelingen zal worden gegeven op basis van het ROA-rapport De arbeidsmarkt naar opleiding en beroep (ROA, 1995). Daarnaast zal ook worden ingegaan op de regio-specifieke ontwikkelingen en de knelpunten in de vacaturevervulling, zoals die geconstateerd worden door de arbeidsbureaus ${ }^{5}$. De vijf grootste beroepsklassen binnen de metalektro zullen worden besproken. Deze vijf beroepen nemen - zowel landelijk als regionaal $-45 \%$ van de totale werkgelegenheid in de metalektro-sector voor hun rekening.

\section{Middenkader functies}

Landelijk beeld

Met een aandeel van $12 \%$ in de totale metalektro-werkgelegenheid zijn de middenkader functies de meest omvangrijke functiecategorie binnen de metalektro-sector. Dit is vooral het gevolg van het grote aantal leidinggevenden in de produktiesfeer. Vergeleken bij de meeste andere van de in totaal 3.1 genoemde beroepen, zijn de werknemers in deze beroepsklasse relatief hoog opgeleid. Veelal heeft men een MBO-opleiding afgerond. De substitutiemogelijkheden tussen middenkader-functionarissen met verschillende opleidingsachtergronden zijn over het algemeen echter erg groot. Dit biedt de werkgevers in de metalektro-sector de nodige flexibiliteit bij het opvullen van deze functies.

Zoals uit figuur 3.1 bleek, zijn de werkzame personen in dit beroep niet erg afhankelijk van de metalektro-sector als werkgever. Slechts $14 \%$ van het totaal aantal werkzame personen in deze beroepsklasse is in dienst bij een metalektro-onderneming. Naast de overige industrie en de bouw bieden ook de handel en de andere dienstensectoren veel werkgelegenheid in deze middenkader functies.

5. Voor de regionale knelpunten analyse is gebruik gemaakt van het PGI, het informatiesysteem van de Arbeidsvoorzieningsorganisatie. 
Figuur 3.1 maakt ook duidelijk dat deze beroepsgroep zich van andere beroepsklassen onderscheidt door het hoge aantal baanopeningen. In de eerste plaats ontstaan er naar verwachting in de komende 5 jaren veel baanopeningen doordat $23 \%$ van het huidige personeelsbestand in deze functie in de komende jaren vervangen moet worden vanwege pensionering e.d. In de tweede plaats breidt de werkgelegenheid in deze beroepsklasse zich uit met $15 \%$ van de huidige werkgelegenheid (uitbreidingsvraag).

\section{Regionaal beeld}

In Zuid-Limburg werken relatief veel middenkader functionarissen in de metalektrosector. $19 \%$ van de totale werkgelegenheid in deze functies doet zich voor in de metaal-elektro tegenover $15 \%$ landelijk. Dit is slechts ten dele te verklaren uit de oververtegenwoordiging van de metalektro in de regionale economie (zie hoofdstuk 2). Voor een ander deel moet het grote "marktaandeel" van de metalektro in het aantal werkenden in deze beroepsklasse worden herleid tot een grotere vraag naar deze beroepsklasse.

Of de beroepsklasse in de regio Zuid-Limburg de komende jaren evenveel kansen biedt voor nieuwkomers op de arbeidsmarkt als landelijk het geval is, is op basis van de momenteel beschikbare gegevens niet te zeggen. Mogelijk werken er twee krachten in tegengestelde richting. De uitbreidingsvraag - landelijk nog goed voor vier van de tien baanopeningen in deze beroepsklasse - zal in deze regio waarschijnlijk geringer zijn vanwege de naar verwachting geringere werkgelegenheidsgroei in de metalektro-sector. Bepalender voor het aantal baanopeningen is echter de vervangingsvraag. Helaas zijn vooralsnog geen regionale prognoses van deze vraagcomponent voorhanden. De landelijk verwachte vervangingsvraag van $23 \%$ is - gezien het hoge percentage ouderen in de totale Zuid-Limburgse beroepsbevolking - mogelijk aan de lage kant.

Machinebank- en plaatwerkers, smeden

\section{Landelijk beeld}

In deze beroepsklasse vinden we machinale metaalbewerkers, machinebankwerkers, plaatwerkers, steenhouwers, smeden en gereedschapsmakers terug. Met een aandeel van $11 \%$ in de totale metalektro-werkgelegenheid vormen zij een van de grootste beroepsklassen in de metalektro-sector.

Het grootste deel van de werkzame personen in deze beroepsklasse beschikt over een opleiding op MBO-leerlingwezenniveau: 53\%. Daarnaast zijn ook veel mensen werkzaam met een VBO-opleiding (31\%). Het aantal werkenden met alleen basison- 
derwijs (10\%) daalt in omvang. De best vertegenwoordigde opleidingsrichtingen zijn mechanische techniek (VBO-niveau), metaalkunde, werktuigbouwkunde, elektrotechniek en motorvoertuigentechniek (allen mbo/leerlingwezen). Machinebank-, plaatwerkers en smeden met een verschillende opleidingsachtergrond zijn tot op zekere hoogte onderling inwisselbaar. Deze substitutiemogelijkheden zijn in deze beroepsklasse echter niet meer dan gemiddeld.

Uit figuur 3.1 bleek dat de vraag voor deze beroepsklasse gedomineerd wordt door de ontwikkelingen binnen de metalektro-sector. Maar liefst $59 \%$ van de in deze beroepsklasse werkzame personen werkt binnen de metaal- en elektrotechnische industrie. Met name de ontwikkelingen binnen de machine-industrie en de metaalproduktenindustrie zijn bepalend voor de ontwikkelingen in deze beroepsklasse. Deze bedrijfsklassen omvatten tezamen $81 \%$ van de metalektro-werkgelegenheid in deze beroepsklasse. Dit alles betekent niet dat de werkzame personen binnen deze beroepsklasse geheel op de metalektro-sector zijn aangewezen. De uitwijkmogelijkheden zijn zelfs groot. De handel, de commerciële dienstverlening en de bouw zijn de belangrijkste alternatieven.

Zoals uit dezelfde figuur bleek, is het verwachte aantal baanopeningen in deze beroepsklasse op landelijk niveau niet meer dan gemiddeld. De ruimte die ontstaat voor nieuwkomers, vloeit vooral voort uit de hoge vervangingsvraag. In de komende jaren gaat waarschijnlijk een aanzienlijk deel van de werkzame personen in deze beroepsklasse met pensioen. Van een uitbreidingsvraag in deze beroepsklasse is echter geen sprake. De daling van de werkgelegenheid, die in de periode 1990-'94 werd ingezet, zet zich naar verwachting ook in de komende 5 jaar door.

Regionaal beeld

Ook in Zuid-Limburg wordt de werkgelegenheid in deze beroepsklasse gedomineerd door de metalektro-sector; het marktaandeel van de sector ligt boven de $50 \%$ van het aantal werkenden. Het aandeel van deze beroepsklasse in de metalektro-sector geeft recht op een vierde plaats in de ranglijst.

De huidige situatie op de regionale arbeidsmarkt voor machinebank-, plaatwerkers en smeden kenmerkt zich nogal eens door een moeizame invulling van de opengevallen arbeidsplaatsen. Uit de bemiddelingsgegevens van het RBA kan worden opgemaakt, dat er op de markt voor bankwerkers geen problemen zijn. Bijna alle vacatures in deze functiecategorie werden door metalektro-bedrijven ingediend. Deze vacatures konden bijna zonder uitzondering worden vervuld. Hieruit is op te maken dat het aanbod in kwalitatief noch kwantitatief opzicht tekort schiet. Van spanningen op de regionale arbeidsmarkt is in deze beroepsklasse derhalve geen sprake. Toch is er enige reden tot ongerustheid. De omloopsnelheid van werkzoe- 
kende bankwerkers in het bemiddelingsbestand blijkt hoog te zijn ${ }^{6}$. Dit duidt erop dat tegenover de ingediende vacatures een relatief geringe "rij" van werkzoekenden staat. Een toename van het aantal ingediende vacatures zou derhalve snel kunnen leiden tot een aanbodtekort. In een andere verwante functiegroep, die van verspaningsvakman, lijkt er reeds sprake te zijn van een tekort aan vaklieden. Bij deze functie is er een hoge omloopsnelheid van de ingeschreven werkzoekenden en een lage vervullingsquote van de openstaande vacatures. De richting waarin het aantal baanopeningen zich gaat ontwikkelen, is zeer bepalend voor de vraag of er op korte termijn nog grotere spanningen op dit arbeidsmarktsegment gaan ontstaan.

Of de regionale ontwikkeling van het aantal baanopeningen in deze beroepsklasse even gematigd zal zijn als de landelijke ontwikkeling, is moeilijk in te schatten. Naar verwachting is er een geringe uitbreidingsvraag in de Zuid-Limburgse metalektrosector. Het is om die reden aannemelijk dat het aantal baanopeningen ook in de regio Zuid-Limburg geheel afhangt van de vervangingsvraag. Prognoses van het aantal baanopeningen zijn op regionaal niveau echter vooralsnog niet voorhanden. De landelijk verwachte vervangingsbehoefte van $24 \%$ lijkt gezien het relatief grote aantal werknemers dat in deze regio aan de vooravond van zijn pensioen staat de regionale vervangingsbehoefte te onderschatten.

Lassers, constructiewerkers en edelsmeden

Landelijk beeld

De lassers, constructiewerkers en edelsmeden vormen qua omvang de derde beroepsklasse in de metalektro-sector. In de beroepsklasse vinden we naast lassers, constructiebank- en -plaatwerkers ook branders, snijders, bankwerkers met onbekende specialisatie en goud- en zilversmeden.

De werkzame personen in deze beroepsklasse zijn vaak laag opgeleid. Bijna de helft van de werknemers beschikt over een VBO diploma. Een aanzienlijk groep werkenden (37\%) heeft echter een diploma op MBO/leerlingwezen niveau. $12 \%$ van de werkzame personen heeft daarentegen slechts basisonderwijs gevolgd. De VBOopleiding mechanische techniek, alsmede de MBO/leerlingwezen-opleidingen metaalkunde en werktuigbouwkunde zijn de meest gevolgde opleidingsrichtingen. In deze beroepsklasse werkzame personen met een verschillende opleidingsachtergrond zijn tot op bepaalde hoogte onderling inwisselbaar. Deze substitutiemogelijkheden zijn echter niet meer dan gemiddeld.

6. Het betreft een analyse op het bestand van niet-werkende werkzoekenden. De omloopsnelheid is berekend als het quotiënt van het aantal ingediende vacatures in 1995 en het aantal beschikbare nnw-ers. 
Zoals bleek uit figuur 3.1, wordt de werkgelegenheid om de beroepsklasse gedomineerd door de metalektro-sector. Daarbij zijn de bedrijfsklassen metaalprodukten-, machine- en transportmiddelenindustrie bepalend voor $95 \%$ van de metalektrowerkgelegenheid in deze beroepsklasse. De werkzame personen in deze beroepsklasse zijn echter niet geheel aangewezen op de metalektro-sector. Vooral de bouwsector is een belangrijk alternatief. De uitwijkmogelijkheden van lassers, constructeurs en edelsmeden zijn echter niet meer dan gemiddeld.

Een andere conclusie die uit de figuur getrokken kan worden, is dat de ontwikkeling van het aantal baanopeningen in deze beroepsklasse achterblijft bij het landelijk gemiddelde. Van uitbreidingsvraag zal in deze beroepsklasse in het geheel geen sprake zijn: de werkgelegenheid krimpt naar verwachting zelfs met $4 \%$. Het aantal baanopeningen wordt dan ook geheel bepaald door de vervangingsvraag. Ook deze component zal zich in de komende 5 jaar naar verwachting slechts matig ontwikkelen. Er gaan in deze beroepsklasse maar weinig personen met pensioen, die bovendien vanwege de verwachte werkgelegenheidsdaling slechts ten dele vervangen zullen hoeven te worden.

\section{Regionaal beeld}

Ook in Zuid-Limburg wordt de beroepsklasse gedomineerd door de metalektrosector. Het "marktaandeel" van de metalektro in deze beroepsklasse ligt boven de vijftig procent. Sterker dan landelijk het geval is, domineert daarbij de metaalproduktenindustrie. Opvallend is verder dat deze beroepsklasse in de Zuid-Limburgse metalektro-sector aanzienlijk minder dominant aanwezig is dan landelijk.

De huidige situatie op de regionale arbeidsmarkt kenmerkt zich - voor zover het de lassers betreft - door een moeizame invulling van openvallende arbeidsplaatsen. Het RBA Zuid-Limburg weet slechts $52 \%$ van de (bijna allemaal door metalektro-ondernemers ingediende) vacatures voor lassers in te vullen. Uit interviews met de consulenten van arbeidsbureaus blijkt, dat dit deels te wijten is aan het feit dat niet alle lassers beschikken over de juiste las-certificaten (MIG/MAG, TIG, electrisch). Bovendien wisselen de werkgevers nogal eens in hun voorkeur tussen de verschillende lastechnieken. De specifieke aansluitingsproblemen tussen vraag en aanbod en de onduidelijkheid die dit alles met zich meebrengt, belemmeren de vacaturevervulling op dit arbeidsmarktsegment.

Of er op regionale arbeidsmarkt voor lassers, constructeurs en edelsmeden in de komende 5 jaar even weinig baanopeningen gaan ontstaan als landelijk het geval is, is moeilijk aan te geven. Vanwege de ongunstige werkgelegenheidsontwikkelingen in de Zuid-Limburgse metalektro-sector zal de uitbreidingsvraag in deze be- 
roepsklasse waarschijnlijk geringer zijn dan landelijk het geval is ${ }^{7}$. Het is daarom waarschijnlijk, dat ook in de regio het aantal baanopeningen geheel is terug te voeren op de vervangingsvraag. Van deze component zijn echter geen regionale prognoses voorhanden. Gezien de vergrijzing van de regionale beroepsbevolking lijkt de landelijke vervangingsvraag voor deze beroepsklasse van $15 \%$ waarschijnlijk de regionale vervangingsbehoefte te onderschatten.

\section{Metaalbewerkers}

\section{Landelijk beeld}

In de beroepsklasse metaalbewerkers vinden we automaatbedienden, metaalpolijsters, slotenmakers, schrootsorteerder, samensteller van voertuigen, controleurs en autokeurmeesters. De beroepsklasse heeft een aandeel van $6 \%$ in de landelijke metalektrowerkgelegenheid en is daarmee de vierde beroepsklasse in de metalektro.

De werkzame personen in deze beroepsklasse zijn veelal laag opgeleid. Maar liefst $20 \%$ van de werkzame personen heeft na het basisonderwijs nooit een voortgezette opleiding afgerond. Een grotere groep (36\%) heeft een VBO-diploma, terwijl slechts $34 \%$ een opleiding op MBO-leerlingwezen niveau heeft afgerond. De substitutiemogelijkheden tussen arbeidskrachten met een verschillende opleidingsachtergrond zijn in dit beroep hoger dan gemiddeld. De meest voorkomende opleidingsrichting is de VBO-opleiding mechanische techniek. De specifieke opleidingsachtergrond van een metaalbewerker lijkt er derhalve weinig toe te doen.

De metaalbewerkers zijn sterk afhankelijk van de metalektro-sector als werkgever. $77 \%$ verdient zijn brood in deze branche. Binnen de branche is de metaalproduktenindustrie de belangrijkste werkgever met een derde van de metalektro-werkgelegenheid in deze beroepsklasse, maar ook andere metalektro-branches bieden veel werkgelegenheid: de machine-, de electrotechnische industrie en de transportmiddelenindustrie zijn gezamenlijk goed voor bijna $60 \%$ van de werkgelegenheid in deze beroepsklasse. Ondanks het grote marktaandeel van de metalektro-sector zijn de uitwijkmogelijkheden van metaalbewerkers hoger dan gemiddeld. Met name de handel is een belangrijke uitwijkmogelijkheid voor de werkenden in deze beroepsklasse.

Op landelijk niveau zal er in de komende jaren naar verwachting weinig ruimte ontstaan voor de instroom van nieuwe metaalbewerkers. Van uitbreidingsvraag zal

7. Ook de CBA-prognoses voor de corresponderende beroepsklassen wijzen dit uit. 
in deze beroepsklasse in het geheel geen sprake zijn: de werkgelegenheid krimpt naar verwachting zelfs met $5 \%$. Het aantal baanopeningen wordt dan ook geheel bepaald door de vervangingsvraag. Ook deze component zal zich in de komende 5 jaren matig ontwikkelen. Er hoeven in deze beroepsklasse maar weinig personen met pensioen, waardoor de vervangingsvraag laag zal zijn (17\%).

\section{Regionaal beeld}

Ook in de regio Zuid-Limburg wordt deze beroepsklasse gedomineerd door de metalektro-sector. In tegenstelling tot het landelijk beeld is daarbij de invloed van de transportmiddelenindustrie allesoverheersend.

De huidige situatie op de regionale arbeidsmarkt laat zich schetsen aan de hand van de bemiddelingsactiviteiten van het RBA. De vacatures worden het vaakst ingediend onder de noemer "produktiemedewerker (metaal)" en "monteur metaal". Uit de vervullingsquote voor produktiemedewerkers in het algemeen blijkt, dat opengevallen arbeidsplaatsen momenteel zonder opvallend veel problemen kunnen worden ingevuld. In getalsmatig opzicht is het aanbod van produktiemedewerkers zelfs groot. De omloopsnelheid van werkzoekende metaalbewerkers is dan ook zeer laag. Binnen de metalektro-sector is er evenmin sprake van grote recruteringsproblemen in deze functiecategorie, zoals blijkt uit de vervullingsquote van $75 \%$. Minder probleemloos is echter de vacaturevervulling in de functies "monteur metaal". Het aantal vacatures is hier echter te laag om op dit punt stellige uitspraken te doen.

Of op regionale arbeidsmarkt voor metaalbewerkers in de komende 5 jaar even weinig baanopeningen gaan ontstaan als landelijk het geval is, is moeilijk aan te geven. Deze baanopeningen zullen waarschijnlijk vooral voortvloeien uit de vervangingsvraag. De landelijke schatting voor de vervanginsvraag (17\%) lijkt gezien de leeftijdsopbouw van de Zuid-Limburgse werkzame beroepsbevolking de vervangingsbehoefte in de regio te onderschatten.

\section{Monteurs en controleurs elektrotechnische installaties}

\section{Landelijk beeld}

In de beroepsklasse monteurs en controleurs elektrotechnische installaties vinden we de elektrotechnisch bankwerker, de elektronica-monteur, de radio- en tv-reparateur, de electriciën, de telefoonmonteur en -installateur en de tester van elektronische produkten. De beroepsklasse heeft een aandeel van $6 \%$ in de landelijke metalektro-werkgelegenheid en is qua grootte de vijfde beroepsklasse binnen de metalektro. 
De werkzame personen in deze beroepsklasse hebben voor het merendeel een opleiding op MBO-leerlingwezen niveau: $62 \%$. Slechts $4 \%$ heeft alleen basisonderwijs, terwijl $23 \%$ een VBO-opleidingsachtergrond heeft. Zowel op VBO- als MBOniveau is de opleiding elektrotechniek de meest aangetroffen opleidingsrichting. In totaal heeft $66 \%$ van de werkenden in deze beroepsklasse deze vakrichting gevolgd. De substitutiemogelijkheden tussen werkenden met een uiteenlopende opleidingsachtergrond zijn in deze beroepsklasse dan ook gering.

De werkzame personen in deze beroepsklasse zijn daarentegen slechts in beperkte mate afhankelijk van de metalektro-sector als werkgever. Slechts $24 \%$ is in deze sector werkzaam. Dit betreft vaak werk in de elektrotechnische industrie. Een groter deel is werkzaam in de bouw. Ook worden de monteurs en controleurs aangetroffen in de dienstensectoren, die samen goed zijn voor een derde van de totale werkgelegenheid in deze beroepsklassen. De uitwijkmogelijkheden van metaalbewerkers naar andere bedrijfssectoren zijn mede hierdoor hoog.

Er zullen in de komende jaren naar verwachting maar weinig baanopeningen ontstaan voor nieuwe monteurs en controleurs. Van uitbreidingsvraag zal in deze beroepsklasse nauwelijks sprake zijn. Het aantal baanopeningen wordt dan ook geheel bepaald door de vervangingsvraag. Deze component zal zich in de komende 5 jaar conform het gemiddelde ontwikkelen: $21 \%$.

Regionaal beeld

De werkzame personen in deze beroepsklasse zijn in Zuid-Limburg anders gespreid over de verschillende bedrijfssectoren dan landelijk. Relatief veel monteurs en controleurs werken in de metalektro-sector. Toch domineert de metalektro ook in ZuidLimburg bij lange na niet de werkgelegenheid in deze beroepsklasse.

De huidige situatie in deze beroepsklasse kenmerkt zich door een weinig problematisch verlopende vacaturevervulling. Dit blijkt uit de bemiddelingsbestanden van het RBA. De meeste vacatures die worden ingediend in deze beroepsklasse, komen binnen onder de noemer monteur elektronica of monteur elektrotechniek. De vervulling van deze vacatures ligt op een gemiddeld niveau $(61 \%)$ en het aanbod van werkzoekenden is in kwantitatief opzicht toereikend, gezien de lage omloopsnelheid. Ook in de metalektro-sector doen zich nauwelijks problemen in de vacaturevervulling voor.

Of er ook in de regio weinig behoefte is aan nieuwkomers, zal waarschijnlijk geheel afhangen van de vervangingsvraag. Regionale prognoses van het aantal baanopeningen zijn echter niet voorhanden. De landelijke schatting van $21 \%$ is, gezien 
de leeftijdsopbouw van de regionale werkzame beroepsbevolking, waarschijnlijk aan de lage kant. 



\section{Opleidingen voor de metaal- en elektrotechnische industrie}

Hoofdstuk 4 gaat in op de opleidingen, die kwalificeren voor een beroep in de metalektro-sector. De aandacht gaat daarbij uit naar het aantal baanopeningen dat de komende jaren naar verwachting zal ontstaan en het percentage werkenden dat in de metalektro-sector werkzaam is. Vier vragen staan daarbij centraal:

1. Welke opleidingsachtergronden hebben de werkenden in de metalektro-sector?

2. Domineert de metalektro-sector de werkgelegenheid voor vaklieden met deze opleidingsachtergronden?

3. Hoe zal de arbeidsmarkt voor werkenden met deze opleidingsachtergronden zich in de komende jaren ontwikkelen?

4. Hoe is de aansluiting tussen de verschillende opleidingstypen en de arbeidsmarkt?

De eerste drie vragen zullen alleen op landelijk niveau worden beantwoord (zie paragraaf 4.1). De laatste vraag zal in paragraaf 4.2 ook op regionaal niveau worden beantwoord (4.2).

\subsection{Marktontwikkelingen en marktaandeel per opleidingscategorie}

Tabel 4.1 geeft een overzicht van de qua aantal werkenden belangrijke opleidingstypen in de metalektro-sector. Uit de tabel blijkt onder andere het relatief grote aantal ongeschoolden (alleen basisonderwijs) dat werkzaam is in deze sector. Met uitzondering van de $\mathrm{HBO}$-opleidng elektrotechniek en technische informatica hebben de meeste andere voor de sector belangrijke opleidingscategoriëen betrekking op opleidingen op VBO en MBO/leerlingwezen niveau.

Om op de eerste drie hoofdvragen een antwoord te formuleren, worden in figuur 4.1 de opleidingen langs twee dimensies gepositioneerd. De eerste dimensie, het aantal baanopeningen dat in de komende jaren naar verwachting gaat ontstaan, refereert aan de marktontwikkelingen binnen de opleidingstypen. De tweede dimensie refereert aan het marktaandeel van de metalektro-sector in de werkgelegenheid voor het desbetreffende opleidingstype. Daarbij kan gekozen worden voor twee varianten. In de eerste variant (het marktaandeel) wordt het aantal in de metalektro-sector werkzame personen met een bepaalde opleidingsachtergrond gerelateerd aan de totale werkgelegenheid voor die opleidingscategorie. Voor deze variant werd gekozen in hoofdstuk 3 . In de tweede variant (het relatieve marktaandeel) wordt het berekende marktaandeel gerelateerd aan het marktaandeel van de grootste concurrent voor de metalektro-sector onder de vragers op het desbetreffende arbeidsmarktsegment, dat wil zeggen de sector waarin de meeste arbeidskrachten met de 
betreffende opleidingsachtergrond werkzaam zijn. Hier zal de laatste variant worden gebruikt omdat deze grootste informatiewaarde heeft voor het in beeld brengen van de concurrentiepositie ${ }^{8}$. De gebruikte gegevens zijn ontleend aan het ROA-rapport De arbeidsmarkt naar opleiding en beroep tot 2000 (ROA, 1995).

Tabel 4.1

Belangrijkste opleiidngsachtergronden in de metalektro-sector in Nederland, gemiddelde 1993'94

\begin{tabular}{lcl}
\hline Opleiding & $\begin{array}{c}\text { Kans op knelpunten in } \\
\text { Aantal } \\
\text { personeelsvoorziening } \\
\text { in 2000 }\end{array}$ & $\begin{array}{l}\text { werkzame personen } \\
\text { 1. Basisonderwijs }\end{array}$ \\
2. VBO mechanische techniek & 71.000 & zeer klein \\
3. MBO/LLW metaalkunde & 48.500 & zeer klein \\
4. MBO/LLW elektrotechniek & 32.000 & zeer klein \\
5. MBO/LLW werktuigbouwkunde & 30.000 & zeer klein \\
6. MAVO, onderbouw HAVO/WWO & 29.000 & zeer klein \\
7. MBO/LLW handel & 29.000 & zeer klein \\
8. VBO bouwtechniek & 15.500 & zeer klein \\
9. VBO elektrotechniek & 12.500 & zeer klein \\
10. HBO electrotechniek/techn. inf. & 12.500 & zeer klein \\
& 11.500 & zeer klein \\
\hline
\end{tabular}

Bron: ROA

Het tweede en het vierde vak

In figuur 4.1 zijn het aantal baanopeningen en het relatieve marktaandeel tegen elkaar afgezet. Twee lijnen delen de figuur in vier vlakken. De horizontale lijn valt samen met het landelijk gemiddelde aantal baanopeningen in de periode 19952000: $22 \%$ van de werkgelegenheid in 1995. De verticale lijn valt samen met de punten waarin het marktaandeel van de metalektro-sector even groot is als de grootste concurrent. De in de metalektro-sector werkzame opleidingscategorieën zijn nu ten opzichte van elkaar te positioneren door ze te verdelen over de vier vakken. De grootste opleidingscategorieën binnen de metalektro-sector zijn daarbij genummerd van 1 tot en met 10 (zie tabel 4.1).

8. De metalektro-sector is binnen bijna geen enkele opleidingscategorie dominant. Een marktaandeel van $50 \%$, zoals binnen veel beroepsklasses werd gehaald, komt bij vrijwel geen enkel opleidingstype voor, met uitzondering van de opleiding MBO-metaalkunde. Omdat in dit opzicht de verschillen tussen de diverse opleidingen betrekkelijk klein zijn, biedt het relatieve marktaandeel meer informatiewaarde. Deze maatstaf maakt onderscheid tussen de opleidingen, waarbinnen de metalektro-sector de grootste marktaandeel heeft, en de opleidingen waarbij een andere sector de grootste bron van werkgelegenheid is. 
Figuur 4.1

Verwachte baanopeningen 1995-2000 en relatief marktaandeel met elektro-sector naar opleidingstype

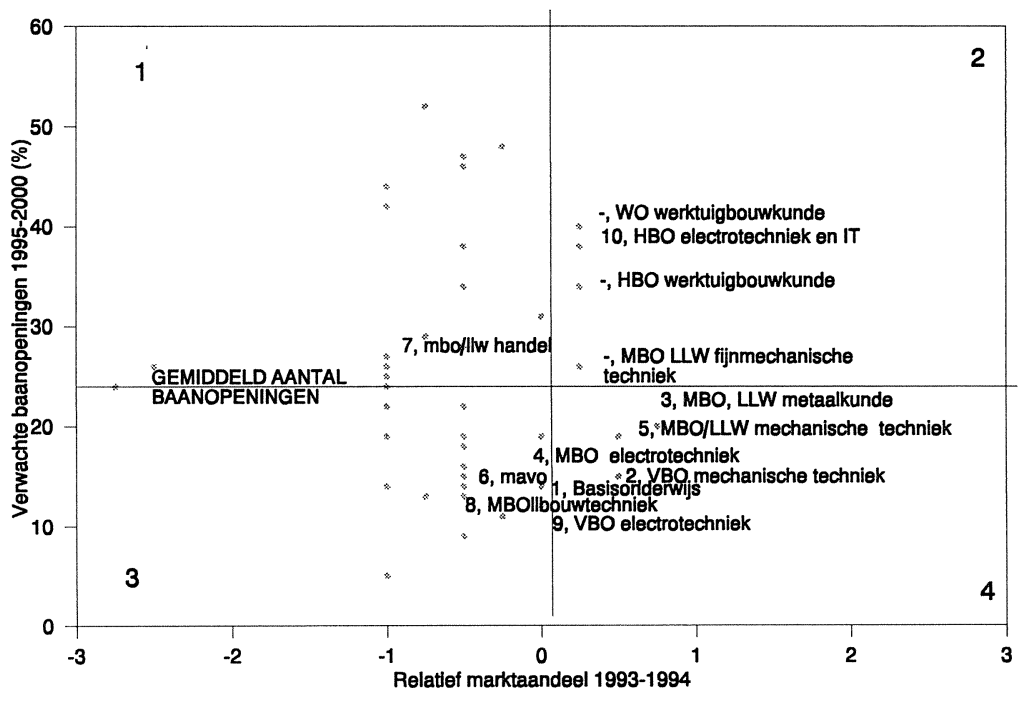

- De opleidingstype-nummers verwijzen naar de rangorde in tabel 4.1

Bron: ROA, 1995

Van de tien meest omvangrijke opleidingscategorieën binnen de metalektro blijken er zeven te behoren tot de vakken 2 en 4 . De metalektro-sector behaalt in deze opleidingscategorieën een marktaandeel dat groter is dan dat van de grootste concurrerende sector. De hogere opleidingen (WO, HBO, en enkele MBO-opleidingen) onderscheiden zich daarbij door een relatief groot aantal baanopeningen; zij bevinden zich dan ook in het tweede vak. Wanneer het aantal baanopeningen vergeleken wordt met de arbeidsmarktinstroom van nieuwkomers dan kunnen de arbeidsmarktperspectieven voor de nieuwkomers op de arbeidsmarkt met deze opleidingsachtergrond getypeerd worden als goed. Omgekeerd betekent dit dat de kans op knelpunten in de personeelsvoorziening bij deze opleidingstypen groot tot zeer groot is. In de volgende paragraaf wordt dieper ingegaan op de landelijke en regionale arbeidsmarktknelpunten bij deze opleidingscategorieën.

De lagere - en tevens meest omvangrijke - opleidingen binnen de metalektrosector onderscheiden zich door een relatief laag aantal baanopeningen en bevinden zich in het vierde vak. De oorzaak voor het lage aantal baanopeningen is gelegen in de lage uitbreidingsvraag voor deze opleidingstypen. Naast de terugval van het aantal banen in functies waarin lager geschoolden veelal werkzaam zijn, speelt ook 
de afnemende vraag naar laaggeschoolden voor deze functies, een belangrijke rol. Wanneer het toekomstig aantal baanopeningen afgezet wordt tegen de verwachte arbeidsmarktinstroom van nieuwkomers, kan de arbeidsmarktsituatie voor deze opleidingen getypeerd worden als matig tot redelijk. De kans op toekomstige knelpunten in de personeelsvoorziening is zeer klein tot klein. In de volgende paragraaf zal hier nader op worden ingegaan.

Het eerste en het derde vak

De overige opleidingen, waaronder drie van de tien grootste opleidingstypen, bevinden zich in het eerste en het derde vak. In deze opleidingscategorieën is de metalektro kleiner dan de grootste concurrerende sector. Van de grootste opleidingen onderscheidt de $\mathrm{MBO} /$ leerlingwezen opleidingsrichting handel zich door een relatief hoog aantal baanopeningen. Wanneer naast het aantal baanopeningen ook het aantal schoolverlaters in beschouwing wordt genomen, kan de arbeidsmarktsituatie voor deze opleidingscategorie als redelijk worden beschouwd. De kans op toekomstige knelpunten in de personeelsvoorziening is zeer klein. De resterende twee grootste opleidingen hebben naar verwachting een gering aantal baanopeningen (vak 3). Wederom kenmerken de lagere opleidingsniveaus (VBO-bouwtechniek en MAVO) zich dus door een lager aantal baanopeningen. De toekomstige arbeidsmarktsituatie voor deze opleidingscategorieën is vanwege het relatief geringe aantal schoolverlaters matig tot redelijk. De toekomstige kans op knelpunten in de personeelsvoorziening is echter zeer klein.

\subsection{Landelijke en regionale knelpunten per opleidingscategorie}

Nu de opleidingen ten opzichte van elkaar gepositioneerd zijn, kan worden ingegaan op de vierde vraag: sluit het aanbod van schooolverlaters aan op de behoeften aan de vraagzijde van de arbeidsmarkt? Deze vraag zal per opleidingscategorie worden beantwoord. De regionalisering van het landelijk beeld kan echter op basis van de momenteel beschikbare gegevens niet verder gaan dan de regio ZuidNederland (i.c. de provincies Limburg en Noord-Brabant). De bespreking van de arbeidsmarktsituatie zal worden toegespitst op de opleidingscategorieën, waarvoor de metalektro-sector het grootste marktaandeel heeft (vak 2 en 4 in figuur 4.1).

Drie indicatoren voor een gebrekkige aansluiting tussen vraag en aanbod op de arbeidsmarkt staan centraal ${ }^{9}$. De eerste indicator, de werkloosheid onder schoolverlaters, vormt een duidelijk signaal voor de omvang van de huidige (kwantitatieve)

9. De eerste en de derde indicator worden ontleend aan Van Smoorenburg en Van der Velden (1995). De tweede indicator is ontleend aan ROA (1995). Onlangs is meer recente schoolverlatersinformatie gepubliceerd in Van Smoorenburg en Willems (1996). 
discrepanties diverse segmenten van de arbeidsmarkt. Daarnaast zal ook de duur van de werkloosheid in ogenschouw worden genomen. De tweede indicator, de kans op toekomstige knelpunten in de personeelsvoorziening (ITKP), geeft aan hoe groot de kans op knelpunten in de personeelsvoorziening in de komende jaren zal zijn. De derde indicator geeft een indruk van de kwalitatieve aansluitingsproblematiek. Het betreft de mate waarin de opleiding volgens schoolverlaters aansluit op de gevonden baan.

\section{VBO mechanische techniek}

\section{Landelijk beeld}

Schoolverlaters van de opleiding VBO mechanische techniek komen vaak terecht in de metalektro-sector (Zie figuur 4.1). Met name in de machine-industrie en de metaalproduktenindustrie zijn veel van deze schoolverlaters werkzaam. De drie belangrijkste beroepen waarin deze schoolverlaters terechtkomen, zijn constructiebankwerker $(9 \%)$, lasser $(6 \%)$ en loodgieter $(5 \%)$.

Slechts 3\% van de schoolverlaters met deze opleidingsachtergrond stond in 1994 als werkloos geregistreerd. De kans dat voor het jaar 2000 nog knelpunten ontstaan in de personeelsvoorziening, is volgens de recente prognoses van het ROA "zeer klein". De baan waarin de schoolverlaters werkzaam zijn, sluit meestal aan bij hun opleidingsniveau (73\%), maar veel minder vaak bij de richting van hun opleiding (19\%). De VBO-ers met deze opleidingsrichting van andere VBO'ers met een technische opleidingsachtergrond, waarvan meer dan de helft een baan vindt die aansluit bij de gevolgde vakrichting. Van grote aansluitingsproblemen is dus geen sprake; wel zijn veel schoolverlaters met deze opleidingsachtergrond werkzaam buiten hun richting.

\section{Regionale situatie}

De machine-industrie speelt in Zuid-Nederland een veel minder grote rol als werkgever van de schoolverlaters van deze opleidingsrichting. Hoewel de cijfers niet representatief hoeven te zijn voor Zuid-Limburg spoort dit gegeven wel met de ondervertegenwoordiging van de machine industrie in deze regio.

Of de Zuid-Nederlandse arbeidsmarkt regio-specifieke aansluitingsproblemen kent, zou moeten blijken uit de werkloosheidspercentages en de "match" tussen baan en opleiding. Hoewel de geregistreerde werkloosheid in Zuid-Nederland wat lager is dan landelijk, zoeken schoolverlaters in Zuid-Nederland aanzienlijk langer naar werk. Maar liefst $14 \%$ is langer dan 4 maanden werkloos, tegen $8 \%$ landelijk. 
Degenen die wel een baan vinden, zijn vaker werkzaam onder hun niveau. Wel sluit de baan vaker aan op de opleidingsrichting dan landelijk het geval is.

\section{MBO-LLW metaalkunde}

\section{Landelijk beeld}

De meeste schoolverlaters van de metaalkunde opleidingen binnen het MBO en leerlingwezen vinden emplooi in de machine-industrie en de metaalproduktenindustrie. Deze schoolverlaters vinden vooral werk in de beroepen lassers, metaaldraaier en constructiebankwerker en onderhoudsmonteur bedrijfsinstallaties.

De geregistreerde werkloosheid onder de schoolverlaters is $8 \%$. Het aantal schoolverlaters dat na 4 maanden zoeken nog geen baan heeft ligt vooral bij het MBO'ers wat hoger dan gemiddeld bij de technisch opgeleiden op dit opleidingsniveau. Vooral bij de KMBO'ers liggen de banen vaak op een lager niveau dan het gevolgde opleidingsniveau. De helft van de schoolverlaters vindt ook emplooi in een functie waarvoor de gevolgde opleiding niet specifiek vereist is. De kans dat zich voor het jaar 2000 wel problemen in de personeelsvoorziening voordoen, is naar verwachting zeer klein.

\section{Regionaal beeld}

$\mathrm{Er}$ is maar heel weinig zicht op de regio-specifieke uitstroom en bestemming van schoolverlaters met deze opleidingsachtergrond. Wel is bekend dat de geregistreerde werkloosheid onder schoolverlaters in deze opleidingscategorie groter is dan landelijk.

\section{MBO Elektrotechniek}

\section{Landelijk beeld}

De metalektro-sektor is, ondanks het feit dat zij een van de grootste werkgevers is voor MBO'ers elektrotechniek, opvallend genoeg niet de sector die recentelijk de meeste schoolverlaters van deze opleiding heeft aangetrokken. De bouw is de grootste concurrent op dit arbeidsmarktsegment, terwijl ook de handel en de zakelijke dienstverlening een fors deel van de schoolverlaters aantrekken. De meeste schoolverlaters zijn werkzaam in de beroepen electriciën-installateur, elektronicamonteur en winkelbediende.

De werkloosheid onder MBO'ers elektrotechniek is hoger dan op andere deelmarkten voor MBO-technici. Bij de MBO-kort opleidingen bedraagt de werkloosheid zelfs 
$16 \%$. Het percentage werkzoekenden dat langer dan 4 maanden bezig is met het zoeken van een baan, verschilt overigens niet dramatisch van andere technische opleidingen op MBO-niveau. De aansluiting van de functies waarin men werk vindt bij de riching van de opleiding is wel duidelijk slechter. De kans dat op termijn problemen in de personeelsvoorziening gaan ontstaan is volgens de prognoses van het ROA zeer klein.

Regionaal beeld.

De aansluitingsproblematiek op de arbeidsmarkt voor MBO'ers elektrotechniek is in Zuid-Nederland anders van karakter dan landelijk. Zo trekt de zakelijke dienstverlening in het Zuiden van het land aanzienlijk meer schoolverlaters. Of dit ook voor Zuid-Limburg geldt, dient echter sterk betwijfeld te worden; de zakelijke dienstverlening is in deze regio immers ondervertegenwoordigd.

De geregistreerde werkloosheid onder schoolverlaters is in Zuid-Nederland lager dan landelijk. Bovendien geven veel meer baanvinders aan, dat hun baan aansluit bij niveau en richting van de gevolgde opleiding. In Zuid-Nederland lijken zich dus (nog) minder aansluitingsproblemen voor te doen, dan landelijk het geval is.

\section{MBO werktuigbouwkunde}

Landelijk beeld

De machine-industrie en de metaalproduktenindustrie zijn de belangrijkste werkgevers voor de schoolverlaters MBO werktuigbouwkunde. De schoolverlaters komen vaak aan de slag als constructiebankwerker (5\%), machine- en onderhoudsmonteur (8\%) of werktuigbouwkundig tekenaar $(12 \%)$.

De geregistreerde werkloosheid onder werktuigbouwkundigen ligt iets onder het gemiddelde van de MBO-technici. Schoolverlaters met deze achtergrond zijn niet vaak langer dan 4 maanden werkloos. De aansluiting tussen de gevonden baan en het niveau en de richting van de opleiding is echter slechter dan bij de meeste andere MBO-techniek opleidingen. De kans dat zich op termijn knelpunten in de personeelsvoorziening voordoen is naar verwachting zeer klein.

Regionaal beeld

Ook in Zuid-Nederland nemen de metalektro-sectoren veel schoolverlaters op. In Zuid-Nederland zijn zij vaker werkzaam als constructiebankwerker. 
Er doen zich maar weinig regio-specifieke aansluitingsproblemen voor. In ZuidNederland zijn schoolverlaters vaker al meer dan 4 maanden op zoek naar werk dan landelijk het geval is. Daarentegen ligt het werkloosheidspercentage onder het landelijk gemiddelde. De aansluiting tussen de functies waarin de schoolverlaters werkzaam zijn en de richting en het niveau van de gevolgde opleiding verschilt niet van het landelijke beeld.

\section{VBO elektrotechniek}

De metalektro-sector is niet de grootste afnemer van schoolverlaters VBO elektrotechniek. De bouwinstallatie, de detailhandel en de reparatiebedrijven gaan de metalektro-sector voor. De beroepen waarin de schoolverlaters doorgaans terecht komen, zijn electriciën-installateurs (bouwnijverheid), hulppersoneel (detailhandel) en onderhoudselectricien (bouwinstallatie).

Bijzondere problemen lijken zich niet voor te doen. De geregistreede werkloosheid is $10 \%$, hetgeen overeenkomst met het gemiddelde beeld van de technische opleidingen op VBO-niveau. Het aantal schoolverlaters dat langer dan 4 maanden werkloos is, is zelfs relatief laag: $9 \%$. De aansluiting van het werk bij de richting en het niveau van de gevolgde opleiding verschilt niet van de oude technische opleidingen op VBO-niveau. Ook de kans dat er op termijn knelpunten gaan ontstaan in de personeelsvoorziening wordt als "zeer klein" ingeschat.

\section{Regionaal beeld}

Ook in Zuid-Limburg verschaffen de bouwinstallatie, de detailhandel en de reparatiebedrijven veel werkgelegenheid aan de schoolverlaters VBO elektrotechniek. Het opvallendste verschil met het landelijke beeld is het grote aantal schoolverlaters dat langer dan 4 maanden werkloos is. Een tweede indicatie voor regio-specifieke aansluitproblemen is de slechte aansluiting van de functies waarin men werk vindt bij de gevolgde opleidingsrichting. 


\section{Samenvatting en conclusie}

De landelijke werkgelegenheid in de metalektro-sector vertoonde tussen 1991 en 1995 een scherp dalende trend. Er zijn geen andere sectoren aan te wijzen waarin de daling van de werkgelegenheid zo fors was als in de metalektro-sector. Hoewel de produktie zich in de meeste andere bedrijfsklassen reeds in 1994 herstelde, wordt een herstel van de werkgelegenheid in de metalektro-sector pas in 1996 voorzien.

De sterke teruggang van de werkgelegenheid kan bezien worden tegen de achtergrond van de hoge conjunctuurgevoeligheid van de metalektro-activiteiten. Niet alleen het hoge omzetaandeel van de conjunctuurgevoelige exporten en investeringen, maar ook het hoge omzetaandeel van de sterk fluctuerende intermediaire leveringen zijn hieraan debet. Vooral de negatieve ontwikkelingen in de bouw en de chemie drukten zwaar op de resultaten in de metalektro. De relatief ongunstige ontwikkeling van de werkgelegenheid kan ook worden bezien tegen de achtergrond van de afstoting van 'randwerkgelegenheid' door de metalektro-sector. Werkzaamheden die niet behoren tot de kernactiviteiten, worden steeds vaker ondergebracht bij toeleveranciers in andere sectoren.

De regionale werkgelegenheid in de metalektro-sector ontwikkelt zich nog ongunstiger dan landelijk. Ook in Zuid-Limburg lijkt de werkgelegenheid zich echter vanaf 1996 te herstellen. De relatief sterke teruggang in de afgelopen jaren kan worden geïnterpreteerd in het licht van de sterkere conjunctuurgevoeligheid van de industrie in deze regio. Niet alleen is de metalektro-sector in deze regio veel sterker afhankelijk van de conjunctuurgevoelige exporten, ook is de branche erg afhankelijk van de zeer conjunctuurgevoelige chemische industrie (DSM). De opleving van de chemie is dan ook een sterke impuls voor de toeleveranciers in de metalektro-sector. Ook de aanwezigheid van de momenteel florerende auto-industrie in de regio Zuid-Limburg is een sterke impuls voor de sector. Daarnaast is de komst van het telecommunicatiebedrijf Libertel van groot belang voor de regio.

De metalektro-sector domineert de werkgelegenheid in een aanzienlijk aantal technische beroepsklassen. Het aantal baanopeningen in deze beroepsklassen zal in de komende jaren naar verwachting beneden het landelijk gemiddelde van $24 \%$ liggen. De ongunstige arbeidsmarktontwikkelingen in de metalektro-beroepsklassen zijn terug te voeren op een geringe uitbreidingsvraag in deze beroepen. De uitbreidingsvraag is in veel van de grootste beroepsklassen zelfs nihil. De geringe groei van de werkgelegenheid in de metalektro-sector is daaraan in belangrijke mate debet. Het aantal baanopeningen is daardoor geheel terug te voeren op de vervangingsvraag. In Zuid-Limburg zou de vervanginsvraag iets boven het landelijk gemid- 
delde kunnen liggen door de relatief hoge leeftijd van de werkzame bevolking. Meer exacte informatie op dit punt ontbreekt vooralsnog. De uitbreidingsvraag in de door de metalektro-sector gedomineerde beroepsklassen is, gezien de ongunstige ontwikkeling van de metalektro-werkgelegenheid, ook in de regio Zuid-Limburg naar alle waarschijnlijkheid nihil.

De metalektro-sector is zeer afhankelijk van het aanbod van technisch opgeleiden, maar domineert bij geen enkele opleiding de totale werkgelegenheid voor werknemers met de desbetreffende opleidingsachtergrond. Het marktaandeel van de metalektro-sector ligt bij geen enkele opleiding boven de $50 \%$. Wel is de metalektro-sector bij veel technische opleidingen de grootste werkgever (het marktaandeel van de metalektro is dan groter dan dat van de grootste op de arbeidsmarkt concurrerende sector). Het arbeidsmarktperspectief voor schoolverlaters van de belangrijkste opleidingstypen voor de metalektro-sector loopt uiteen van goede perspectieven voor de afgestudeerden van de technische opleidingen op HBO- en WOniveau tot matige perspectieven voor diverse MBO- en VBO-opleidingen. Voor de werkgevers betekent dit dat de kans op toekomstige knelpunten in de personeelsvoorziening vooral groot is bij het hoger geschoold technisch personeel. 


\section{Literatuur}

Centraal Planbureau (1995), Centraal Economisch Plan 1995, Sdu: Den Haag.

Economisch Technologisch Instituut Limburg (1995), L-SEV, ETIL: Maastricht.

Jacobs, D. en De Man, A.P. (1995), Clusters en concurrentiekracht, Samson: Alphen aan de Rijn/ Zaventem.

Kamers van Koophandel en Fabrieken in Limburg (1994), Resultaten enquête regionale bedrijfsontwikkeling 1993 (ERBO '93).

Kamers van Koophandel en Fabrieken in Limburg (1995), Resultaten enquête regionale bedrijfsontwikkeling 1994 (ERBO '94).

Kuijper, J. en G. Van Duren (1995), Het Nederlandse metalectro-cluster,vol 80, nr 4035, blz. 1081-1083.

Landelijk Bureau Arbeidsvoorziening (1995), Regionale Arbeidsmarktprognose 1995-2000, O\&A rapport 95-07, LBA: Rijswijk.

Landelijk Dienstverlenend Centrum voor Studie- en Beroepskeuzevoorlichting (1995), De regionale arbeidsmarkt '94: Regio Noord, Oost en Zuid, LDC: Leeuwarden.

Piore, M. en Sabel, C. (1984), The Second Industrial Divide: Possibilities for Prosperity, Basic Books: New York.

Rabobank (1994), Cijfers en Trends: branches uit het midden- en kleinbedrijf, Rabobank: Utrecht.

Rabobank (1995), Cijfers en Trends: branches uit het midden- en kleinbedrijf, Rabobank: Utrecht.

Researchcentrum voor Onderwijs en Arbeidsmarkt (1995), De arbeidsmarkt naar opleiding en beroep tot 2000, ROA-R-1995/3, ROA: Maastricht.

Smoorenburg, M.S.M. van, R.K.W van der Velden (1995), Schoolverlaters op de arbeidsmarkt, ROA: Maastricht, LDC: Leeuwarden.

Smoorenburg, M.S.M. van, E.J.T.A. Willems (1996), Schoolverlaters tussen onderwijs en arbeidsmarkt 1995, ROA-R-1996/3, ROA: Maastricht. 

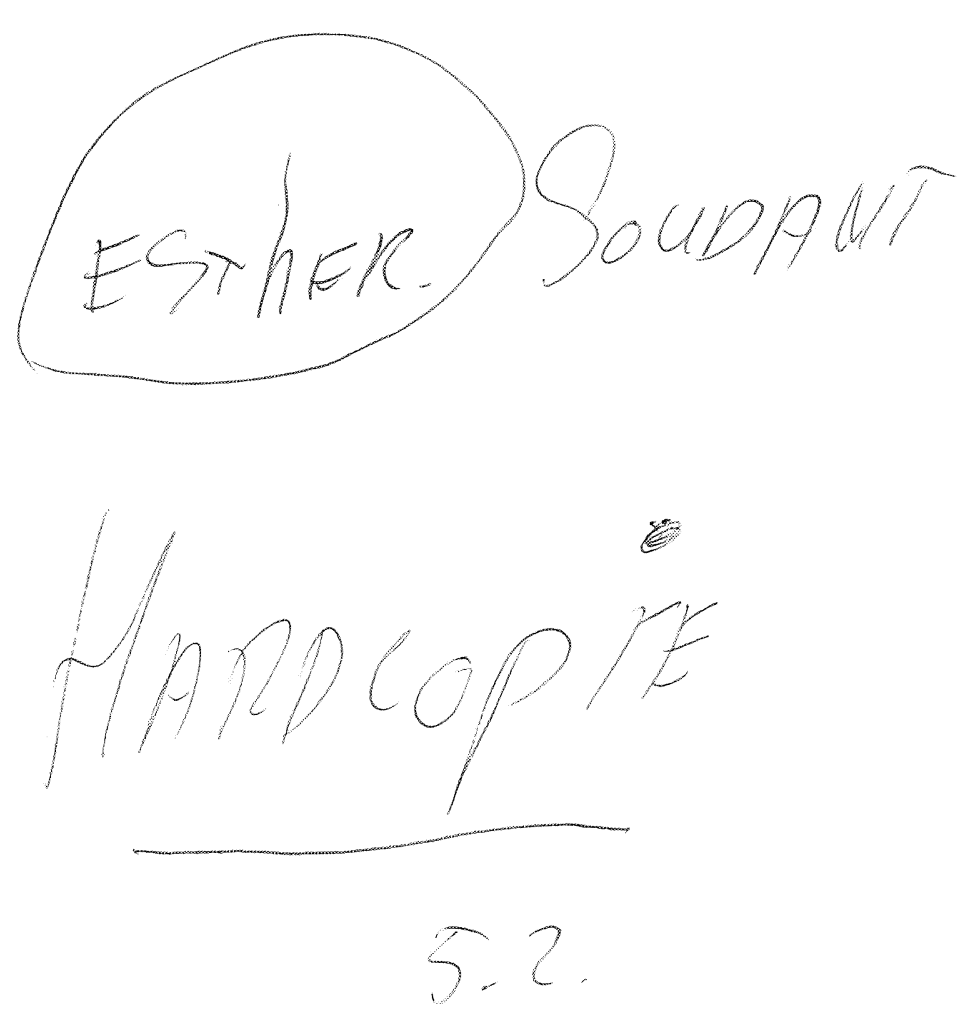